\title{
Ticks and Tick-Borne Diseases of Livestock in the Middle East and North Africa: A Review
}

\author{
Nighat Perveen (D), Sabir Bin Muzaffar (D) and Mohammad Ali Al-Deeb *(D) \\ Department of Biology, United Arab Emirates University, Al-Ain 15551, UAE; 201790740@uaeu.ac.ae (N.P.); \\ s_muzaffar@uaeu.ac.ae (S.B.M.) \\ * Correspondence: m_aldeeb@uaeu.ac.ae; Tel.: +971-3-713-6527
}

check for updates

Citation: Perveen, N.; Muzaffar, S.B.; Al-Deeb, M.A. Ticks and Tick-Borne Diseases of Livestock in the Middle East and North Africa: A Review. Insects 2021, 12, 83. https:/ / doi.org/ $10.3390 /$ insects 12010083

Received: 28 December 2020

Accepted: 13 January 2021

Published: 19 January 2021

Publisher's Note: MDPI stays neutral with regard to jurisdictional claims in published maps and institutional affiliations.

Copyright: (c) 2021 by the authors. Licensee MDPI, Basel, Switzerland. This article is an open access article distributed under the terms and conditions of the Creative Commons Attribution (CC BY) license (https:/ / creativecommons.org/licenses/by/ $4.0 /$ )
Simple Summary: The Middle East and North Africa represent a hyper arid region of the world. Humans in these regions have historically kept domestic livestock usually under harsh environmental circumstances. With recent human development, especially in the Middle East, the livestock industry has increased. Livestock is affected by ticks and tick-borne diseases on which there has been relatively few studies in this region. This review paper aims to (i) examine the diversity of ticks infesting livestock, (ii) assess the variety of pathogens in animals and humans, and (iii) to identify gaps in our understanding of tick biology and tick-borne disease transmission in the region. We found 55 tick species on livestock including camels, cows, goats and sheep, belonging to eight genera. Fifteen tick-borne pathogens were reported from livestock in the region. We highlight the magnitude of the tick problem in the region and evaluate the control efforts currently in place. We suggest that disease control and prevention could be achieved effectively through collaborative work among all stakeholders such as funding international research projects and establishing joint control programs to combat cross-border movement of ticks.

Abstract: Ticks are important vectors of an array of viral, bacterial and protozoan pathogens resulting in a wide range of animal and human diseases. There is limited information in the literature about tick species in the Middle East and North Africa (MENA) countries, even though they have suitable climate and vegetation for ticks and their hosts. We reviewed the occurrence of tick species and the pathogens they transmit from the MENA on published papers from 1901-2020. We found taxonomic records of 55 tick species infesting livestock representing the following eight genera: Ornithodoros, Otobius, Amblyomma, Dermacentor, Haemaphysalis, Hyalomma, Ixodes, and Rhipicephalus. In addition, 15 pathogens were recorded causing diseases of significance, with Crimean-Congo hemorrhagic fever, theileriosis, babesiosis and anaplasmosis being widely distributed diseases in the region. In recent decades, there has been increasing trends in disease occurrence and movement associated with global movement of humans and global trade of animals. We suggest that disease control and prevention could be achieved effectively through good integration between public health, veterinary medicine and animal management, and ecological approaches. We recommend further research in the areas of tick ecology and tick born-disease transmission. Furthermore, we suggest evaluation and improvement of disease control policies in the region.

Keywords: Arab countries; tick distribution; tick fauna; tick-borne diseases; pathogens

\section{Introduction}

Ticks play a major role in transmitting infectious diseases. Emerging or re-emerging infectious diseases are important global problems of great concern to humans as well as to animal health, with many pathogens being able to infect multiple species [1-4]. With increasing antimicrobial resistance among bacterial pathogens, there has been an increase in the occurrence of zoonotic diseases, sometimes causing widespread outbreaks with considerable domestic animal, wildlife and human morbidity and mortality [4]. 
Therefore, infectious diseases have been recognized as an increasing threat to the general public and animal husbandry. Accelerating climate change carries serious threats for public health and society. Global warming and the unstable climate are playing an everincreasing role in driving the global emergence, resurgence and redistribution of infectious diseases [5]. Globalization and climatic abnormalities have allowed parasites to invade into new geographic areas or establishing ranges in common localities, giving rise to epidemics and epizootics worldwide [1-3,6].

The Arabian Peninsula is globally important as a source of energy, with vast oil and gas reserves that supply the energy demands for the entire world. Consequently, this area went through a vast development and changes. One of the side effects of this development has been the expansion of farming, particularly in the Arabian Peninsula, primarily to support the demands of the rising population [7]. Camels, cows, buffaloes, sheep and goats are farmed using a combination of traditional and modern farming techniques [8]. These animals produce considerable amounts of milk, meat, wool and hides [9] and ticks constitute a major threat to the livestock industries in the MENA (Middle East and North Africa). Ticks have great significance from economic, veterinary, and human health perspectives because of their capacity to transmit a variety of diseases [10]. The ixodid tick genus Hyalomma alone causes enormous losses to the products arising from camels and other livestock across MENA region [11-13]. The roles of diverse assemblages of ticks as vectors and reservoirs of pathogens and their impacts on livestock are not well understood or characterized, although many ticks and tick-borne diseases are known from the Arab region.

The aim of this review is to determine the tick-borne diseases and tick fauna prevailing in the Arab countries. A clear understanding of the abundance of tick species, their role as reservoirs and vectors of pathogens, as well as their geographical distribution, is pivotal in assessing the threat of disease outbreaks and controlling tick-borne diseases in the future.

The objectives of our study were to:

- Review the diversity of ticks of livestock in the MENA region;

- Review the variety of pathogens transmitted by ticks, with especial emphasis on emerging or re-emerging tick-borne diseases;

- Identify gaps in the science of tick biology and tick-borne disease transmission in the region and provide recommendations on the management of ticks and tick-borne diseases in the region.

\section{Methodology}

\subsection{Data and References Collection}

We used Google Scholar, Science Direct, Scopus, Web of science and PubMed to collect the available research papers about ticks, tick-borne diseases and pathogens in Arab countries. We also searched for resources like reports that include tick species and tickborne diseases in MENA countries. Two hundred and ninty four references have been used in this review paper. For each Arab country, we searched relevant literature by using the following keywords: 'the name of the country', 'ticks', 'tick species', 'tick-borne diseases', 'tick-borne pathogens', 'tick distribution', and 'livestock'. The list of the ticks presented here includes almost all species on livestock from Arab world reported in published papers and books.

\subsection{Tick Nomenclature}

For nomenclature, we presented tick species names according to Guglielmone et al. [14]. In this paper, all the old tick names are replaced by the names presented in the aforementioned checklist. For example, the genus Boophilus is replaced by Rhipicephalus and the species Hyalomma detritum is replaced by Hyalomma scupense, Hyalomma erythraeum is replaced by Hyalomma impeltatum. 


\section{Geography of Arab Countries}

The Arab World consists of 22 countries in the MENA region: Algeria, Bahrain, Comoros, Djibouti, Egypt, Iraq, Jordan, Kuwait, Lebanon, Libya, Mauritania, Morocco, Oman, Palestine, Qatar, Saudi Arabia, Somalia, Sudan, Syria, Tunisia, United Arab Emirates, and Yemen [15] (Figure 1). These states occupy an area extending from the Atlantic Ocean to the Zagros Mountains in southwest Asia [16]. The overall total population of the Arab nations in the world is estimated to be approximately 427 million [17].

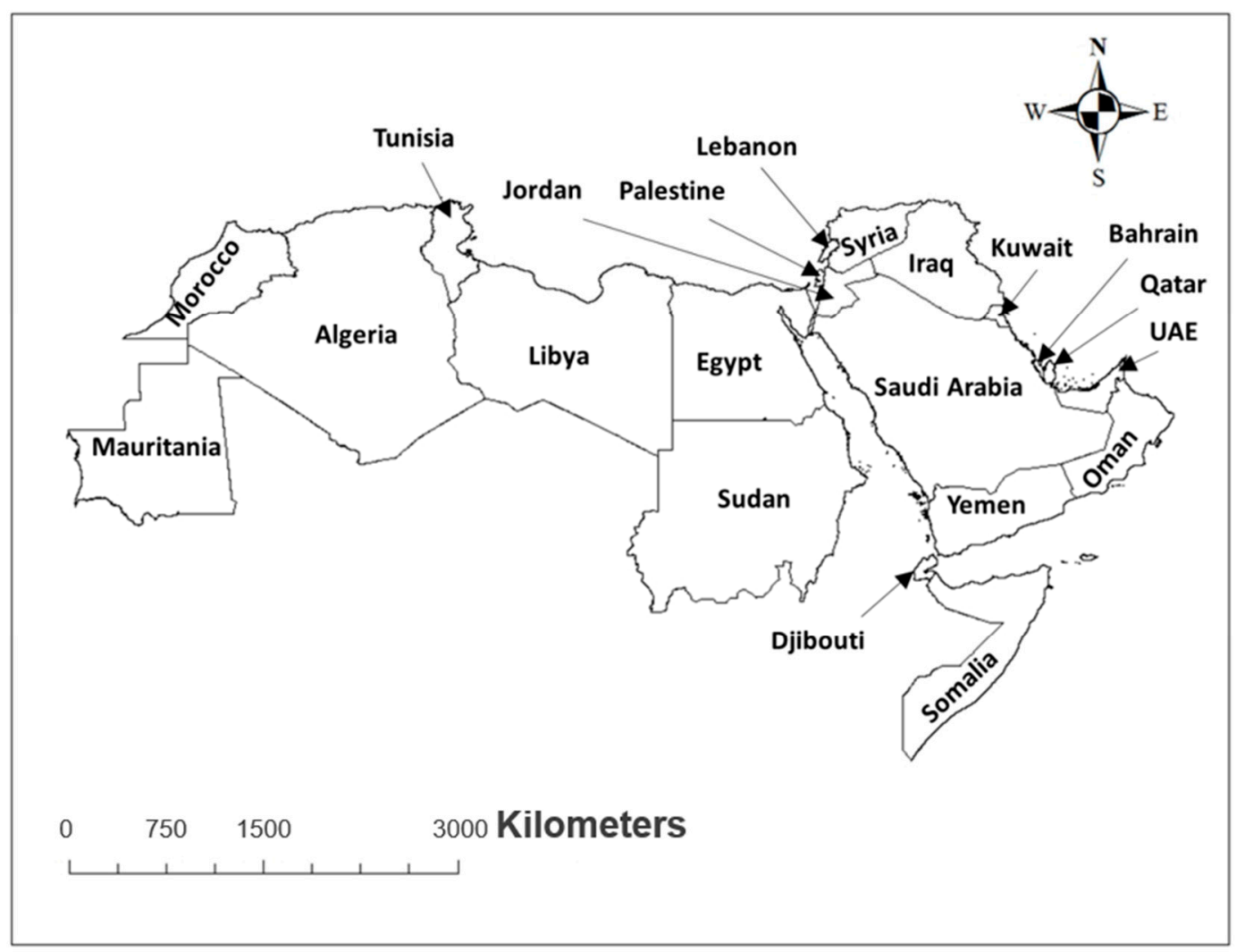

Figure 1. Regional map showing Arab countries.

The Arab countries occupy $14,291,469 \mathrm{~km}^{2}$, which comprises approximately $10.2 \%$ of the world's land mass. Out of this, $72.45 \%$ is located in Africa and $27.55 \%$ is located in Asia. This region comprises of two distinct parts, eastern and western. Generally, the Asian part of the Arab World is the Arab East while the African part is the Arab West [18,19].

Ninety percent of the region consists of arid, semi-arid and dry sub-humid areas. The area is characterized by harsh environment, limited water resources and arable lands. Throughout its long history these lands were the main source of grain and animal production $[16,18]$.

\section{Biogeography of Ticks}

About $80 \%$ of the world's cattle are infested with ticks. As a result, ticks are economically important ectoparasites of livestock. Ticks have negative effect on their vertebrate hosts due to blood feeding causing irritation, allergic dermal reactions, severe paralysis and tick toxicosis $[20,21]$. The economic loss due to tick-borne diseases among ruminants in tropical and subtropical areas is calculated to be several billion dollars annually [22,23]. Generally, the climate of the Arabian Peninsula is characterized by hot dry summers and mild winters with periods of high relative humidity (especially in the coasts) [24]. North Africa, in comparison has a more Mediterranean influence in its climate, although the central portions have arid deserts. Ixodid ticks are distributed in areas where they have 
sufficient animal hosts to sustain their complex life cycles. Hard ticks with two-host or three-host life cycles must occur in distributions that overlap with all their hosts (assuming that different instars feed on different host species). In the case of livestock, ticks could potentially use a combination of livestock species to complete their life cycles. In some cases, species such as wild rodents or insectivores (such as hedgehogs) could be used at least for the earlier stages (larvae and nymphs). These species are especially important in the traditional farming systems (such as izbas or local farm enclosures), where livestock holding areas are accessed by small mammals $[25,26]$.

\section{Diversity and Distribution of Ticks in Arab Countries in Middle East and North Africa}

\subsection{Tick Species Diversity in MENA Region}

A total of 55 species of ticks in eight genera have been documented from livestock in North Africa and the Arabian Peninsula (Table 1). The soft ticks (Argasidae) are represented by two genera, Ornithodoros and Otobius. Ornithodoros savignyi appears to be the most widespread, being recorded from most of the Middle East and into parts of North Africa. The hard ticks (Ixodidae) are represented by six genera (Amblyomma, Dermacentor, Haemaphysalis, Hyalomma, Ixodes and Rhipicephalus) of which H. impeltatum, H. dromedarii, $R$. annulatus and $R$. sanguineus are widely distributed in the MENA region. Among these, Hyalomma dromedarii is the most common tick with high prevalence due to large-scale camel farming.

Arab countries have a suitable habitat for ticks, however, taxonomic studies on tick species in most countries are very limited. The majority of taxonomic studies on ticks of the Arab world were generally focused on hard ticks. The maximum numbers of tick species from livestock are documented in Egypt, Sudan and Jordan (Table 1). Hyalomma and Rhipicephalus are the most common genera reported from livestock in almost all Arab countries. Hyalomma genus serves as the vector and reservoir of CCHF virus [27]. In several countries, we found a small number of published papers on ticks' species and tick-borne pathogens. This indicated the presence of a gap in the research dedicated to tick and tick-borne diseases. There is also need to look into the various aspects of tick distribution to manage future emerging and re-emerging tick-borne diseases and disease movement especially Arab countries which are sharing borders with each other.

Table 1. Tick species distribution in Arab countries.

\begin{tabular}{|c|c|c|c|c|c|}
\hline Families & Genera & Species & Arab Countries & Hosts & References \\
\hline \multirow[t]{7}{*}{ Argasidae } & Ornithodoros & O. erraticus & Iraq, Jordan, Saudi Arabia & Animals & {$[28,29]$} \\
\hline & & O. foleyi & Oman, Libya & Farm animals & {$[29,30]$} \\
\hline & & O. lahorensis & Jordan & & [28] \\
\hline & & O. salahi & Egypt, Jordan & & {$[28,31]$} \\
\hline & & O. savignyi & $\begin{array}{l}\text { Algeria, Egypt, Lebanon, Libya, } \\
\text { Mauritania, Oman, Saudi Arabia, Yemen }\end{array}$ & Camels & {$[29,32-36]$} \\
\hline & & O. tholozani & Egypt, Libya, Jordan & Humans & {$[28,35,37]$} \\
\hline & Otobius & O. megnini & Iraq & Buffaloes & {$[38]$} \\
\hline \multirow[t]{7}{*}{ Ixodidae } & Amblyomma & A. gemma & Saudi Arabia, UAE, Yemen & Cows, camels & {$[29,39,40]$} \\
\hline & & A. lepidum & Egypt, Iraq, Saudi Arabia, Sudan, UAE & Livestock, camels & {$[29,39,41,42]$} \\
\hline & & A. marmoreum & Egypt & Camels & {$[41]$} \\
\hline & & A. variegatum & $\begin{array}{c}\text { Egypt, Oman, Saudi Arabia, Sudan, } \\
\text { Yemen }\end{array}$ & Camels & {$[29,33,41,43]$} \\
\hline & & A. latum & Saudi Arabia, Yemen & Domestic animals & {$[29,40]$} \\
\hline & Dermacentor & D. marginatus & Algeria, Lebanon & Cattle & {$[44,45]$} \\
\hline & Haemaphysalis & H. erinacei & Algeria, Iraq, Jordan & Animals & {$[28,46]$} \\
\hline
\end{tabular}


Table 1. Cont.

\begin{tabular}{|c|c|c|c|c|c|}
\hline Families & Genera & Species & Arab Countries & Hosts & References \\
\hline & & H. indica & Oman & & [29] \\
\hline & & H. parva & Iraq, Libya, Jordan & Domestic animals & {$[28,35,47,48]$} \\
\hline & & H. punctata & Algeria, Lebanon, Tunisia & Domestic animals & {$[45,49,50]$} \\
\hline & & H. sulcata & $\begin{array}{l}\text { Iraq, Jordan, Saudi Arabia, } \\
\text { Tunisia, Yemen }\end{array}$ & Sheep & {$[28,33,46]$} \\
\hline \multirow{17}{*}{\multicolumn{2}{|c|}{ Hyalomma }} & H. anatolicum & $\begin{array}{c}\text { Egypt, Iraq, Jordan, Kuwait, Lebanon, } \\
\text { Oman, Saudi Arabia, Sudan, Syria, UAE, } \\
\text { Yemen }\end{array}$ & Livestock & {$[40,46,47,51,52]$} \\
\hline & & H. arabica & Yemen & Goats, sheep & [33] \\
\hline & & H. asiaticum & Iraq & Cattle, sheep & [52] \\
\hline & & H. dromedarii & $\begin{array}{l}\text { Algeria, Egypt, Iraq, Jordan, Kuwait, } \\
\text { Mauritania, Oman, Qatar, Saudi Arabia, } \\
\text { Sudan, Tunisia, UAE, Yemen }\end{array}$ & Camels & {$[33,41,43,53-55]$} \\
\hline & & H. excavatum & $\begin{array}{l}\text { Algeria, Egypt, Iraq, Jordan, Lebanon, } \\
\text { Libya, Saudi Arabia, Sudan, Syria, } \\
\text { Tunisia, UAE, Yemen }\end{array}$ & Cattle, camels & {$[33,41,52,54,56]$} \\
\hline & & H. franchinii & Libya, Tunisia & Camels, sheep & {$[30,50]$} \\
\hline & & H. hussaini & UAE & Livestock & [39] \\
\hline & & H. impeltatum & $\begin{array}{c}\text { Algeria, Egypt, Iraq, Jordan, Kuwait, } \\
\text { Libya, Mauritania, Oman, Qatar, Saudi } \\
\text { Arabia, Sudan, Syria, Tunisia, UAE, } \\
\text { Yemen }\end{array}$ & Camels, cattle, goats & {$[39,41,52-54,57,58]$} \\
\hline & & H. impressum & Algeria, Mauritania, Sudan & Camels & {$[53,57]$} \\
\hline & & H. lusitanicum & Algeria & Cattle & {$[44,49]$} \\
\hline & & H. marginatum & $\begin{array}{l}\text { Algeria, Egypt, Iraq, Jordan, Kuwait, } \\
\text { Libya, Syria, Tunisia, UAE, Yemen }\end{array}$ & Camels, cattle, sheep & {$[47,52,54,56,59]$} \\
\hline & & H. nitidum & Mauritania & & [36] \\
\hline & & H. rufipes & $\begin{array}{l}\text { Algeria, Egypt, Libya, Mauritania, } \\
\text { Oman, Saudi Arabia, Sudan, Yemen }\end{array}$ & Camels, cows & {$[41,53]$} \\
\hline & & H. scupense & Algeria, Iraq, Jordan, Sudan, Tunisia & Cattle, sheep & {$[28,46,52,56,59]$} \\
\hline & & H. schulzei & Jordan, Kuwait, Lebanon, Saudi Arabia & Domestic animals & {$[11,28,48]$} \\
\hline & & H. truncatum & Egypt, Mauritania, Sudan, UAE & Livestock, camels & {$[39,41,57]$} \\
\hline & & H. turanicum & Egypt, Iraq, Jordan, Libya, Saudi Arabia & Sheep, goats & {$[46,48,52]$} \\
\hline \multirow{3}{*}{\multicolumn{2}{|c|}{ Ixodes }} & I. hoogstraali & Oman & & [29] \\
\hline & & I. ricinus & Algeria, Tunisia & Cattle, sheep & {$[50,56,60]$} \\
\hline & & Ixodes sp. & Jordan & Animals & [28] \\
\hline \multirow{9}{*}{\multicolumn{2}{|c|}{ Rhipicephalus }} & R. annulatus & $\begin{array}{l}\text { Algeria, Egypt, Iraq, Jordan, Kuwait, } \\
\text { Lebanon, Libya, Oman, Sudan, Syria, } \\
\text { Tunisia, Yemen }\end{array}$ & Cattle & {$[33,41,51,54,61,62]$} \\
\hline & & R. appendiculatus & Sudan, UAE & Livestock, camels & [63] \\
\hline & & R. bursa & $\begin{array}{c}\text { Algeria, Iraq, Jordan, Lebanon, Libya, } \\
\text { Tunisia }\end{array}$ & Sheep, goats & {$[46,47,59]$} \\
\hline & & R. camicasi & $\begin{array}{c}\text { Egypt, Jordan, Saudi Arabia, Sudan, } \\
\text { Yemen }\end{array}$ & Sheep & {$[28,41]$} \\
\hline & & R. decoloratus & Libya, Sudan, Yemen & Cattle & {$[30,57,63,64]$} \\
\hline & & R. evertsi & Libya, Mauritania, Sudan, UAE, Yemen & Livestock, camels & {$[30,39,65]$} \\
\hline & & R. geigyi & Mauritania & Livestock & [57] \\
\hline & & R. guilhoni & Egypt, Mauritania, Sudan & Sheep & {$[41,57]$} \\
\hline & & R. kohlsi & $\begin{array}{l}\text { Jordan, Iraq, Jordan, Saudi Arabia, } \\
\text { Yemen }\end{array}$ & Goats, sheep & {$[33,46]$} \\
\hline
\end{tabular}


Table 1. Cont.

\begin{tabular}{|c|c|c|c|c|c|}
\hline \multirow[t]{9}{*}{ Families } & Genera & Species & Arab Countries & Hosts & References \\
\hline & & R. microplus & Libya & Goats & {$[30]$} \\
\hline & & R. muhsamae & Sudan & Cattle & [66] \\
\hline & & R. praetextatus & Saudi Arabia, Sudan & Livestock & {$[67]$} \\
\hline & & R. pulchellus & Egypt, UAE & Camels, livestock & {$[43,68]$} \\
\hline & & R. sanguineus & $\begin{array}{l}\text { Algeria, Egypt, Iraq, Jordan, Kuwait, } \\
\text { Lebanon, Libya, Mauritania, Oman, } \\
\text { Saudi Arabia, Sudan, Syria, Tunisia, } \\
\text { UAE, Yemen }\end{array}$ & Livestock & {$[33,59,65,68]$} \\
\hline & & R. simus & Sudan, Yemen & Sheep, cattle, camels & {$[33,68,69]$} \\
\hline & & R. sulcatus & UAE & Livestock, camels & [39] \\
\hline & & R. turanicus & $\begin{array}{c}\text { Algeria, Egypt, Iraq, Jordan, Lebanon, } \\
\text { Oman, Saudi Arabia, Sudan, Tunisia, } \\
\text { Yemen }\end{array}$ & Cattle, sheep, goats & {$[41,46,47,51,59]$} \\
\hline
\end{tabular}

\subsection{Tick Distribution by Country}

\subsubsection{Algeria}

Ticks are well-known to transmit pathogens which threaten the health and welfare of companion animals and man in Algeria. In 1923, O. savignyi was reported in Wargla as a parasite of camels [32]. In recent years, the scope and importance of ticks and emergent tickborne diseases have been increased dramatically in Algeria and 16 tick species have been reported from livestock. During 1981-1983, ticks were collected for two years from cattle in Algeria and separated into six genera and twelve species including R. bursa, R. turanicus, $R$. sanguineus, $R$. annulatus, I. ricinus, $H$. punctata, D. marginatus, $H$. scupense, $H$. impeltatum, H. marginatum, H. excavatum and H. lusitanicum [49]. Same kind of study was conducted in Northern Algeria between May 2001 and November 2003 on various mammals and ticks were recognized at species level as $R$. sanguineus, $H$. marginatum, $H$. scupense, $R$. bursa and R. turanicus [59]. However, I. ricinus ticks were collected on cattle and identified, in Northeastern Algeria from December 2005 to March 2006 [60]. Djerbouh et al. [53] determined tick species including $H$. dromedarii, $H$. rufipes, $H$. impeltatum, and $H$. impressum from camels in four regions of Southern Algeria. Whereas 11 species of ticks were recorded on domestic animals including H. punctata, D. marginatus, R. sanguineus, R. bursa, H. lusitanicum, H. scupense, H. excavatum, H. marginatum and I. ricinus during a study conducted in 2012, 2013 in Algeria [56]. Five genera including Hyalomma, Rhipicephalus, Dermacentor, Ixodes, Haemaphysalis and sixteen species consist of O. savignyi, R. bursa, R. turanicus, $R$. sanguineus, $R$. annulatus, I. ricinus, $H$. punctata, D. marginatus, $H$. dromedarii, $H$. rufipes, $H$. impressum, $H$. scupense, H. impeltatum, H. marginatum, H. excavatum and H. lusitanicum have been reported in Algeria from livestock according to our review (Table 1).

\subsubsection{Egypt}

Ticks, their feeding habits and other disease causing aspects have been reported in early historical time from Egypt [70]. Over a number of years studies have been carried out in Egypt on ticks of migratory birds and wildlife that may transmit pathogens of man and animals [37,71]. Various tick species from Egypt have been reported to infest camels, cows, buffaloes, and sheep [62,72]. O. savignyi was described in a report on African Ixodoidae as an Egyptian tick specimen [73]. The genera Hyalomma, and Rhipicephalus comprise the most important ixodid ticks infesting animals, specifically $H$. excavatum, $H$. dromedarii, H. impeltatum, H. marginatum, R. annulatus, and R. sanguineus [62]. The cattle tick, $R$. annulatus, is considered to be the most important economic pest infesting cows in Egypt. H. dromedarii, H. impeltatum, H. excavatum, H. anatolicum, H. truncatum, H. marginatum, $H$. rufipes, H. turanicum, R. annulatus, R. sanguineus, $R$. turanicus, $R$. guilhoni, $R$. camicasi, A. lepidum, A. marmoreum, and A. variegatum, were collected from different localities in 
Egypt. Hyalomma species were found on camels and cows. R. annulatus was found only on cows, Rhipicephalus species found on camels and sheep, Amblyomma species were found on imported camels [41]. For detection of piroplasmids such as Babesia and Theileria, ticks were collected from sheep, goats, cattle and camels during 2001 and identified as $R$. appendiculatus, $R$. bursa, $R$. turanicus and $H$. parva on sheep, H. excavatum and $H$. sulcata on goats, $H$. lusitanicum on cattle and $H$. dromedarii, $H$. impeltatum, $H$. marginatum and $H$. anatolicum on camels. Two pathogens B. ovis and T. ovis were detected in livestock [74]. Whereas in another study H. dromedarii, A. lepidum, A. variegatum, and R. pulchellus were found on camels and T. annulata was detected in H. dromedarii [43]. Asmaa et al. [51] conducted a study to determine the associated causes of tick infestations in ruminants and reported that the $R$. annulatus is the most dominant tick species affecting livestock followed by $H$. anatolicum and $R$. turanicus. In a similar study from July to October 2008, AbdelShafy et al. found that cows were infested with $H$. excavatum and $R$. annulatus and camels were infested with $H$. dromedarii, $H$. impeltatum, and $H$. marginatum [54]. Furthermore, a study was carried out during the period from December 2014 to November 2015. A total of 1540 ticks were collected, four ixodid tick species; H. dromedarii, A. lepidum, A. variegatum, and R. pulchellus were found on camels [43]. So far, twenty-two tick species from four genera have been recorded on livestock in Egypt including H. excavatum, H. dromedarii, $H$. impeltatum, $H$. marginatum, $H$. anatolicum, $H$. truncatum, $H$. rufipes, $H$. lusitanicum, $H$. turanicum, $H$. sulcata, $H$. parva, $R$. appendiculatus, $R$. bursa, $R$. annulatus, $R$. sanguineus, $R$. turanicus, R. guilhoni, R. camicasi, R. pulchellus, A. lepidum, A. marmoreum, and A. variegatum (Table 1).

\subsubsection{Iraq}

Ticks and tick-borne diseases constitute a major challenge for livestock health and production in Iraq [75]. Iraq has a huge population of small ruminants estimated at 10 million heads in 2018 [76], and these animals produce considerable amounts of milk, meat, wool, skin and contribute in Iraq's economy. Hoogstraal and Kaiser [77] listed 21 species from several genera including Argas, Ornithodoros, Haemaphysalis, Hyalomma, Ixodes and Rhipicephalus. Ticks of domestic animals are relatively well documented in Iraq $[46,52,75,77-94]$. Sheep and goats are main domestic animals and play an integral in the agricultural economy. They are raised in large numbers throughout the country for their meat, milk and wool [79] and are subject of tick infections with both ixodid and argasid ticks [80]. Twelve tick species, namely $R$. kohlsi, R. annulatus, R. leporis, $R$. turanicus, R. bursa, O. erraticus, H. erinacei, H. sulcata, H. scupense, $H$. turanicum, and $H$. anatolicum were reported [46]. A study on hard ticks affecting cattle, sheep, and goats indicated that cattle were infested with $H$. marginatum and $H$. anatolicum while $R$. bursa, $R$. turanicus, H. parva, and Hyalomma spp. were reported from sheep and goats. The peaks of infestation occurred in the middle of June until end of July [47]. However, in another study, the high infestation was reported in May and July months, respectively. Two genera (Hyalomma and Rhipicephalus) were recorded from 521 collected ticks from sheep and cattle, and 13 species were identified; H. anatolicum, $H$. excavatum, H. asiaticum, $H$. marginatum, $H$. turanicum, $H$. scupense, $H$. impeltatum, $R$. turanicus, $R$. bursa, $R$. sanguineus, $R$. annulatus, R. kohlsi, and Hyalomma spp. The most encountered tick species was H. anatolicum in Hyalomma genus, R. turanicus in Rhipicephalus genus [52]. The literature review revealed that Rhipicephalus, Hyalomma and Haemaphysalis are the main genera infesting livestock in Iraq $[8,46,52,79,81,82,84,86-90,95-97]$ (Table 1).

\subsubsection{Jordan}

Few studies have been carried out on tick fauna $[48,98,99]$ and the Jordanian ticks are poorly studied as compared to neighboring countries [47,100-102]. Based on the collection made during 1952-1954, Hoogstraal and Kaiser [40] reported on the tick fauna. That collection contained several species of both ixodid and argasid ticks. They found R. kohlsi infesting sheep and goats. To define the tick fauna associated with domestic ungulate 
animals, El-Rabie et al. [48] collected fourteen species and subspecies of ixodid ticks including H. parva, H. sulcata, R. sanguineus, R. bursa, R. kohlsi, R. annulatus, H. anatolicum, $H$. excavatum, $H$. marginatum, $H$. turanicum, $H$. scupense, $H$. impeltatum, $H$. dromedarii, and $H$. schulzei, representing three genera (Hyalomma, Rhipicephalus, and Haemaphysalis) from native sheep, goats, camels and cattle. Haemaphysalis parva was the most common species among the 9545 specimens examined. Although Saliba et al. [28] reported argasid including Argas sp., Ornithodoros coniceps, O. erraticus, Ornithodoros tholozani, O. salahi, O. lahorensis and 17 ixodid species comprising of $H$. marginatum, $H$. rhipicephaloides, $H$. anatolicum, $H$. dromedarii, $H$. impeltatum, H. schulzei, H. scupense; $R$. sanguineus, $R$. turanicus, $R$. camicasi, R. bursa, H. erinacei, H. sulcata, H. parva, R. annulatus, R. kohlsi, and Ixodes sp. from East Jordan and the West Bank. No major attention was given to the tick's role in transmission of tick-borne pathogens. Twenty nine tick species from six genera including Haemaphysalis, Hyalomma, Rhipicephalus, Ixodes, Ornithodoros and Argas have been reported in Jordan. However, we have not included ticks from genus Argas in Table 1, because in Arab countries almost all ticks belong to this genus reported from birds/wildlife.

\subsubsection{Kuwait}

Very little work has been carried out on ticks infesting ruminants. Converse and Moussa [103] collected ticks in May-June in 1973 in Kuwait, Iraq and Yemen and described the species as H. dromedarii, H. impeltatum, H. schulzei. Further, four tick species including $R$. annulatus, $H$. anatolicum, $H$. marginatum, and $R$. sanguineus have been reported in 1999 in Kuwait in Disease Vector Ecology Profiles (DVEPs) that summarize unclassified literature on medically important arthropods, vertebrates and plants that may adversely affect in regions around the world [29]. Seven tick species including $R$. annulatus, H. dromedarii, $H$. impeltatum, H. schulzei, $H$. anatolicum, $H$. marginatum, and $R$. sanguineus have been documented from Kuwait (Table 1).

\subsubsection{Lebanon}

Limited data is available about tick presence in domestic ruminants in Lebanon. Six tick species have been reported to be endemic in Lebanon: $R$. annulatus, $R$. sanguineus, H. anatolicum, H. excavatum H. schulzei, and D. marginatus [104-106]. Lately, research was conducted with the aim of providing an analysis of tick presence and distribution. The ticks were randomly collected from domestic ruminants (cattle, sheep, and goats) at 37 farms, in six provinces between June and September 2014. Ticks belonged to four Ixodidae genera: Rhipicephalus, Haemaphysalis, Dermacentor and Hyalomma and seven species: $R$. annulatus, $R$. turanicus, $R$. sanguineus, $R$. bursa, $H$. anatolicum, $H$. punctata and D. marginatus. $R$. turanicus and $H$. anatolicum were found on cattle, sheep, and goats, $R$. annulatus on cattle and sheep, R. sanguineus, D. marginatus and H. punctata on sheep and goats, while $R$. bursa was collected only from sheep. Some of the identified species were recorded for the first time [45]. However, in 2018, only five tick species were recorded as H. anatolicum, $R$. annulatus, $R$. bursa, R. sanguineus sensu lato, and R. turanicus from farm ruminants. Spotted fever group Rickettsiae were molecularly identified and characterized in these ticks [107]. Recently, three tick species (H. punctata, H. parva, D. marginatus) are identified from human hosts [108]. In Lebanon, ten tick species comprising D. marginatus, H. anatolicum, H. schulzei, H. excavatum, H. parva, H. punctata, R. bursa, R. annulatus, R. sanguineus, and R. turanicus have been documented in the literature (Table 1 ).

\subsubsection{Libya}

A number of studies on animal parasitology in Libya were carried out before World War II by Italian workers [109] and later by Hoogstraal and Kaiser [35]. Italian authors were mainly interested in tick-borne human diseases and reported O. foleyi (vector of tick bite fever) [110], O. tholozani (vector of relapsing fever) [111] and R. sanguineus (vector of boutonneuse fever) [112]. Hoogstraal and Kaiser [35] provided details concerning 14 species of ticks from Libya. However, there are considerable gaps in tick research in the 
country. In 1991, Beesley and Gabaj [113] identified R. bursa, R. microplus, and R. decoloratus during 4 years survey in Libya on cattle, goats, sheep and camels. Though, $R$. bursa was originally reported from Libya [114], this identification was considered incorrect [115]. In 1992, thirteen species of ixodid ticks and two species of argasid ticks were documented from farms in Libya such as $R$. annulatus, $R$. microplus, $R$. decoloratus, $R$. sanguineus, $R$. evertsi, $R$. bursa, $H$. anatolicum, $H$. excavatum H. dromedarii, $H$. franchinii, $H$. impeltatum, $H$. rufipes, H. turanicum, and O. foleyi. Hyalomma, Rhipicephalus, Argas and Ornithodoros were the main genera. $H$. dromedarii was found abundant on camels, $H$. impeltatum on sheep and $H$. excavatum on cattle. $H$. dromedarii was the most abundant tick found overall [30]. Fifteen species have been documented in Libya including $R$. annulatus, $R$. microplus, $R$. decoloratus, R. sanguineus, R. evertsi, R. bursa, $H$. anatolicum, H. excavatum H. dromedarii, $H$. franchinii, $H$. impeltatum, $H$. rufipes, $H$. turanicum, O. tholozani and O. foleyi (Table 1 ).

\subsubsection{Mauritania}

In Mauritania, a demographic transition occurred between the 1970s and 2000s, characterized by massive rural-to-urban migration. Nomadic habits, such as possessing domestic animals, were maintained. In cities with a high population density of humans, especially in areas where zoonoses are prevalent, this practice represents a major risk for human populations [65]. In 2003, 38 persons were infested with Crimean-Congo hemorrhagic fever (CCHF) virus in Mauritania [65]. A study was conducted to investigate the magnitude and conditions of emergence of this first urban CCHF outbreak in Mauritania. Ticks collected from animals in livestock markets represented two genera (Hyalomma and Rhipicephalus) and six species of ticks (H. dromedarii, H. impeltatum, H. rufipes, Hyalomma sp., R. sanguineus and $R$. evertsi). Members of the genus Hyalomma, the principal vector of CCHF virus, were found in the same proportion as genus Rhipicephalus [65]. Subsequently, eight tick species were reported to be infested with CCHFV (A. variegatum, $R$. decoloratus, R. geigyi, $H$. dromedarii, H. impeltatum, H. impressum, H. rufipes, H. truncatum, and R. guilhoni $[57,65]$. In 2008, Sylla et al. reported two soft ticks Ornithodoros sonrai and O. savignyi, and seven hard ticks $H$. excavatum, $H$. dromedarii, $H$. impeltatum, $H$. impressum, $H$. rufipes, $H$. nitidum and $H$. truncatum to document the climate change effects and distribution of ticks (Acari: Ixodida) in Senegal and Mauritania [36]. Fifteen tick species have been reported from Mauritania, for example $H$. dromedarii, $H$. impeltatum, H. excavatum, $H$. rufipes, $R$. sanguineus, R. evertsi, A. variegatum, R. decoloratus, R. geigyi, H. impressum, H. nitidum, H. truncatum, $R$. guilhoni, O. sonrai and O. savignyi (Table 1 ).

\subsubsection{Oman}

Oman has relatively high diversity of flora and fauna especially certain arthropod parasites involved in disease transmission [116]. Ticks and their associated hosts have been reported in Oman since 1980 [117]. Papadopoulos et al. reported the following tick species from Oman: O. foleyi, O. sonrai, Haemaphysalis indica, H. anatolicum, H. dromedarii, $H$. impeltatum, H. marginatum, H. turanicum, H. arabica and R. sanguineus [118]. Further work revealed $A$. variegatum, $H$. anatolicum, $H$. dromedarii, $H$. rufipes and Rhipicephalus spp. from cattle, camels and goats [119]. Twelve tick species have been reported from Oman including $A$. variegatum, $R$. annulatus, $H$. anatolicum, $H$. dromedarii, $H$. impeltatum, $H$. rufipes, R. sanguineus, O. foleyi, O. savignyi, H. indica, I. hoogstraali and H. turanicus [29] (Table 1).

\subsubsection{Qatar}

Tick fauna and tick-borne diseases are poorly studied in Qatar. Two species of ticks, H. dromedarii and H. impeltatum, have been reported on camels from Qatar [55,58] (Table 1).

\subsubsection{Saudi Arabia}

The tick fauna associated with domestic animals is relatively well known in the Saudi Arabia [25,26,100,120]. Various tick species are indigenous to Saudi Arabia [25,26,121-123]. Hoogstraal et al. [100] documented 37 tick species and sub-species infesting livestock and 
wild animals and recognized various tick-host relationships. In a study of two consecutive years 1990 and 1991, and 8772 ticks were collected from livestock all across the Saudi Arabia, including one argasid (A. persicus) and 15 ixodid species (A. variegatum, A. gemma, R. kohlsi, H. sulcata, H. anatolicum, H. excavatum, $H$. arabicum, $H$. dromedarii, $H$. impeltatum, $H$. rufipes, $H$. turanicum, H. schulzei, Rhipicephalus camicasi, R. praetextatus, and R. turanicus) [67]. H. dromedarii is the most prevalent species in Saudi Arabia [124]. Al-Shammery et al. conducted a study to find differentiation between common tick species using molecular biology techniques and identified $H$. dromedarii and $R$. annulatus. Both tick species were collected from infested camels and cattle in the animals resting house at Hail region [125]. Literature review revealed that Amblyomma, Haemaphysalis, Hyalomma and Rhipicephalus are the major genera comprising of seventeen species infesting livestock in Saudi Arabia (Table 1).

\subsubsection{Sudan}

Sudan includes tropical forest, various types of forested and un-forested grasslands, semi-desert, and extreme desert. A large proportion of the ticks of tropical Africa occurs in Sudan. Among the large numbers of specimens studied from a wide variety of hosts, 63 tick species were listed infesting variety of domestic and wild animals including reptiles and birds [126]. Whereas Karrar et al. [127] mentioned 16 ticks species in their study of ecology and host-relationships of ticks infesting domestic animals in Kassala Province. Jongejan et al. [128] identified twenty-four adult ixodid tick species, infesting livestock and some wildlife hosts along the Blue and White Nile. More than 70 species of ticks are identified from Sudanese tick fauna, many of which are proven vector of major tick-borne diseases [129-131]. Three genera (Hyalomma, Amblyomma, and Rhipicephalus) and various species of ticks were identified from cattle, sheep, goat and camels. These include $A$. lepidum, A. variegatum, H. anatolicum, H. dromedarii, H. impeltatum, H. rufipes, $H$. impressum, $H$. truncatum, H. scupense, R. annulatus, R. decoloratus, R. evertsi, R. guilhoni, R. muhsamae, $R$. praetextatus, $R$. appendiculatus, $R$. simus and $R$. sanguineus $[64,66,69,132]$. Recently, four genera and fourteen species of ticks reported on cattle. These were R. evertsi, $R$. decoloratus, $R$. sanguineus, $R$. turanicus, $R$. camicasi, $R$. annulatus, $H$. dromedarii, $H$. impeltatum, $H$. rufipes, $H$. anatolicum, H. truncatum, H. excavatum, A. variegatum, and A. lepidum [63,133]. Overall, 22 species belonging to four genera have been documented from livestock in Sudan through literature (Table 1).

\subsubsection{Syria}

The livestock sector has a significant impact on the Syria's economy. The central region is ideal for livestock farming with ample grazing lands. Grazing dairy cattle in pasture may acquire the infection during tick infestation [134]. Six tick species have been reported in 1999 including $R$. annulatus, H. anatolicum, H. excavatum, H. impeltatum, H. marginatum and $R$. sanguineus [29] (Table 1).

\subsubsection{Tunisia}

Little is known about tick species and tick-borne diseases in Tunisia. Fourteen tick species were reported from Tunisia in different time periods by different researchers. $H$. scupense, H. marginatum, H. impeltatum, H. excavatum, H. rufipes, R. turanicus, $R$. sanguineus, and $R$. bursa were reported from cattle, $H$. dromedarii from camels, $I$. ricinus, $H$. punctata $R$. annulatus, $H$. sulcata, $H$. scupense and $H$. franchinii ticks were documented from animals such as sheep, goats and cows (Table 1) [50,135-141].

\subsubsection{United Arab Emirates (UAE)}

In the UAE, there are limited studies on the ticks and tick-borne diseases of domestic animals including camels, cattle, sheep and goats. However, ticks are reported round the year from camels in recent findings [142], which are continuous threat to livestock industry in UAE and people who are in close contact with these animals. Therefore, there could be 
more chances of emergence and re-emergence of tick-borne diseases. Various tick species including $H$. anatolicum, $H$. excavatum, $H$. impeltatum, $H$. dromedarii, $H$. marginatum, $H$. truncatum, H. hussaini, R. appendiculatus, R. evertsi, R. pulchellus, R. sulcatus, A. gemma and A. lepidum were identified from livestock and camels during an outbreak of Crimean-Congo hemorrhagic fever in the UAE in 1994-1995 [39]. In 2010-2011, a study was conducted for screening of tick-borne diseases (protozoan and bacterial diseases) in Al-Ain, UAE and camel tick was identified as $H$. dromedarii on molecular basis [143]. In addition, in 20102011, H. dromedarii was reported with high prevalence (98\%) from UAE [144]. Recently, $H$. scupense and $H$. rufipes are reported from camels in annual report of Central Veterinary Research Laboratory in UAE [145]. Fifteen species have been recorded from livestock including camels in the UAE (Table 1).

\subsubsection{Yemen}

The earliest report on ticks was prepared by Hoogstraal and Kaiser [40] who reported the results of a survey made in 1951; most of the species of ticks infested all types of domestic livestock and they included potential vectors of various important cattle diseases, notably theileriosis, babesiosis, anaplasmosis and heart-water. Pegram et al. [33] reported several tick species from camels, cattle, goats and sheep. Each tick species commonly infesting livestock recorded as transmitting viruses (and some also rickettsiae) causing human illness. Between 1300 and $2000 \mathrm{~m}$ in altitude, A. variegatum was more abundant on camels than on cattle and while cattle were infected with R. annulatus. Below $1500 \mathrm{~m}$, R. kohlsi was more abundant on goats than on sheep and H. sulcata was found on sheep. Whereas H. dromedarii Koch was prevalent on livestock and H. excavatum was on camels. $H$. anatolicum, H. impeltatum and H. rufipes, H. arabica, $R$. evertsi, $R$. simus, $R$. sanguineus and O. savignyi ticks were also reported from various domestic animals. However in 1987, ten species of ticks were collected in the survey from the five hosts (cattle, sheep, goats, camels and donkeys): A. variegatum, $R$. annulatus, $R$. kohlsi, H. excavatum, $H$. dromedarii, $H$. arabica, $H$. rufipes, $R$. evertsi, $R$. sanguineus, and $R$. simus [146]. In another study, ticks of the group of $R$. sanguineus collected from camels, cattle, sheep and goats were examined. Adult ticks of three species in the group were identified: $R$. camicasi, $R$. turanicus, and $R$. sanguineus s.s. Host relationships and ecological affinities were also analyzed [68]. Nine species of ticks were reported in 1999 including A. variegatum, R. annulatus, H. anatolicum, $H$. excavatum, H. dromedarii, $H$. impeltatum, $H$. rufipes, $H$. truncatum and $R$. sanguineus (Anonymous, 1999). While Indigenous sheep were randomly selected and examined for presence of ticks from 2010 to 2011. Seven species of ixodid ticks were identified including $R$. sanguineus, $R$. decoloratus, $R$. evertsi, H. marginatum, A. variegatum, $R$. annulatus, and $H$. sulcata [147]. Nineteen species of ticks have been reported from Yemen including $A$. variegatum, R. annulatus, R. kohlsi, H. excavatum, H. dromedarii, H. impeltatum, H. anatolicum, $H$. arabica, $H$. truncatum, $H$. rufipes, $R$. evertsi, $R$. sanguineus, $R$. simus, $R$. decoloratus, $H$. marginatum, H. sulcata, R. camicasi, R. turanicus and O. savignyi (Table 1 ).

\subsection{Common Ticks of the MENA Region}

Several tick species have common and widespread distribution in the MENA region. For example, $H$. impeltatum and $R$. sanguineus were reported in 15 countries, followed by $H$. dromedarii that was in turn found in 13 countries (Figure 2) covering a wide geographical distribution. These findings show that countries which have common tick species need to conduct joint research projects especially amongst countries with share borders where tick cross-border movement is a very likely mechanism of disease spreading. In addition, when a tick species is reported in 15 countries, this raises concerns about tick-borne disease transmission between these countries through the movement of people or livestock. For example, malignant theileriosis could be vectored by H. impeltatum to sheep and goats in the 15 counties in which it is found (Table 1). Likewise, the same could be said about the probable spread of ehrlichiosis and babesiosis in the countries where $R$. sanguineus is found. 
Thus, international cross-border management strategies involving all countries must be in place to curb the threat of tick-borne diseases.

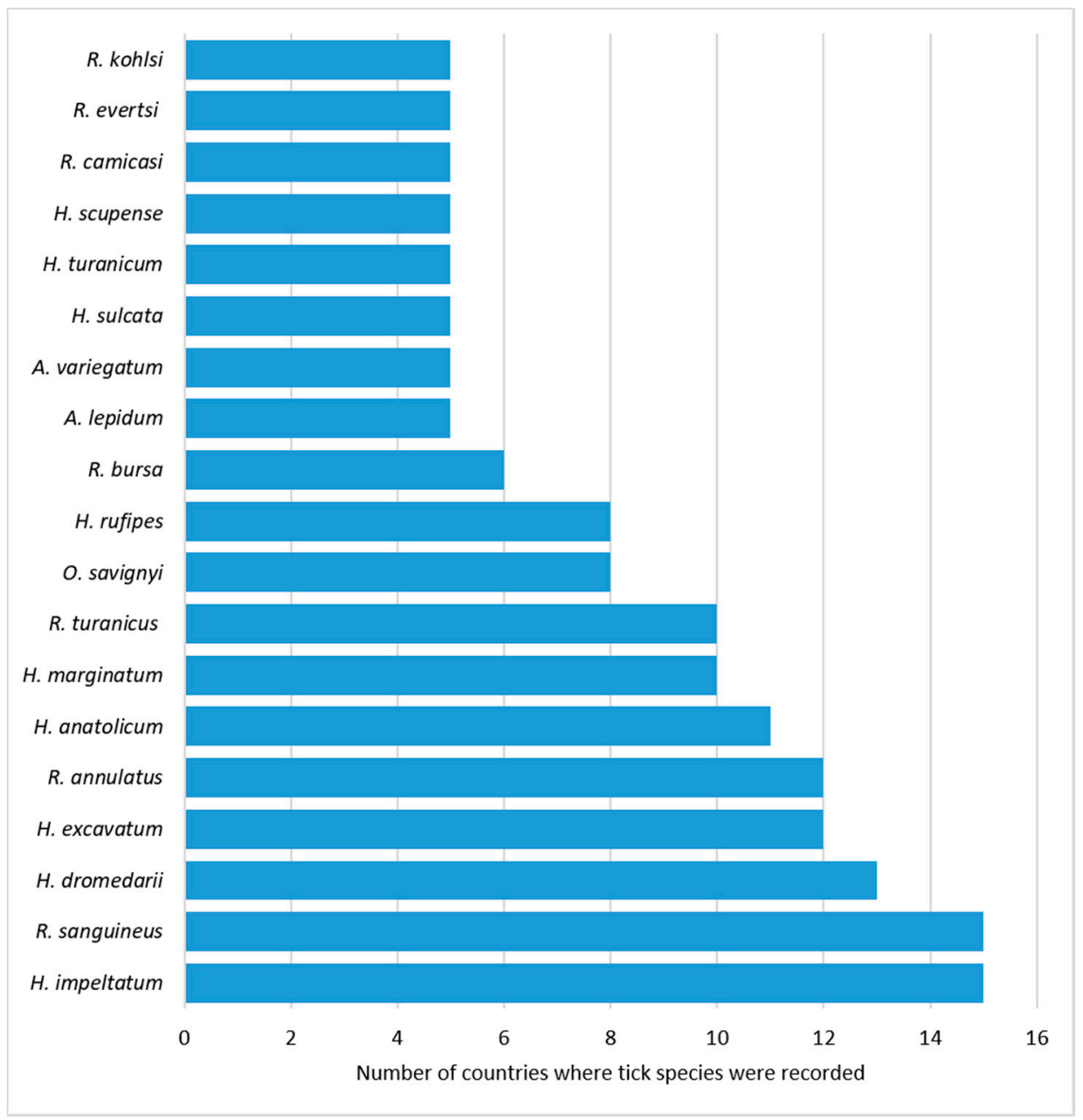

Figure 2. Tick species reported in more than four countries in the MENA (Middle East and North Africa) region.

This review paper shows that Sudan, Jordan, and Egypt has the largest number of reported tick species $(\mathrm{N}=22)$ followed by Yemen, Iraq, and Saudi Arabia $(\mathrm{N}=19,17,17)$, respectively (Figure 3). These findings have two interpretations. First, the high number of reported tick species in one country could be a result of conducting more research projects and the availability of entomologists in the country. Second, it is likely that there are more ticks in these countries, which calls for establishing effective tick management programs because they are at higher risk of tick-borne diseases compared to countries with less tick species. Moreover, countries such as Qatar, Syria, and Kuwait need to check if they have enough tick surveys in place to make sure that the low numbers are not the result of inadequate screening. The same applies to the other countries with lower tick numbers. 


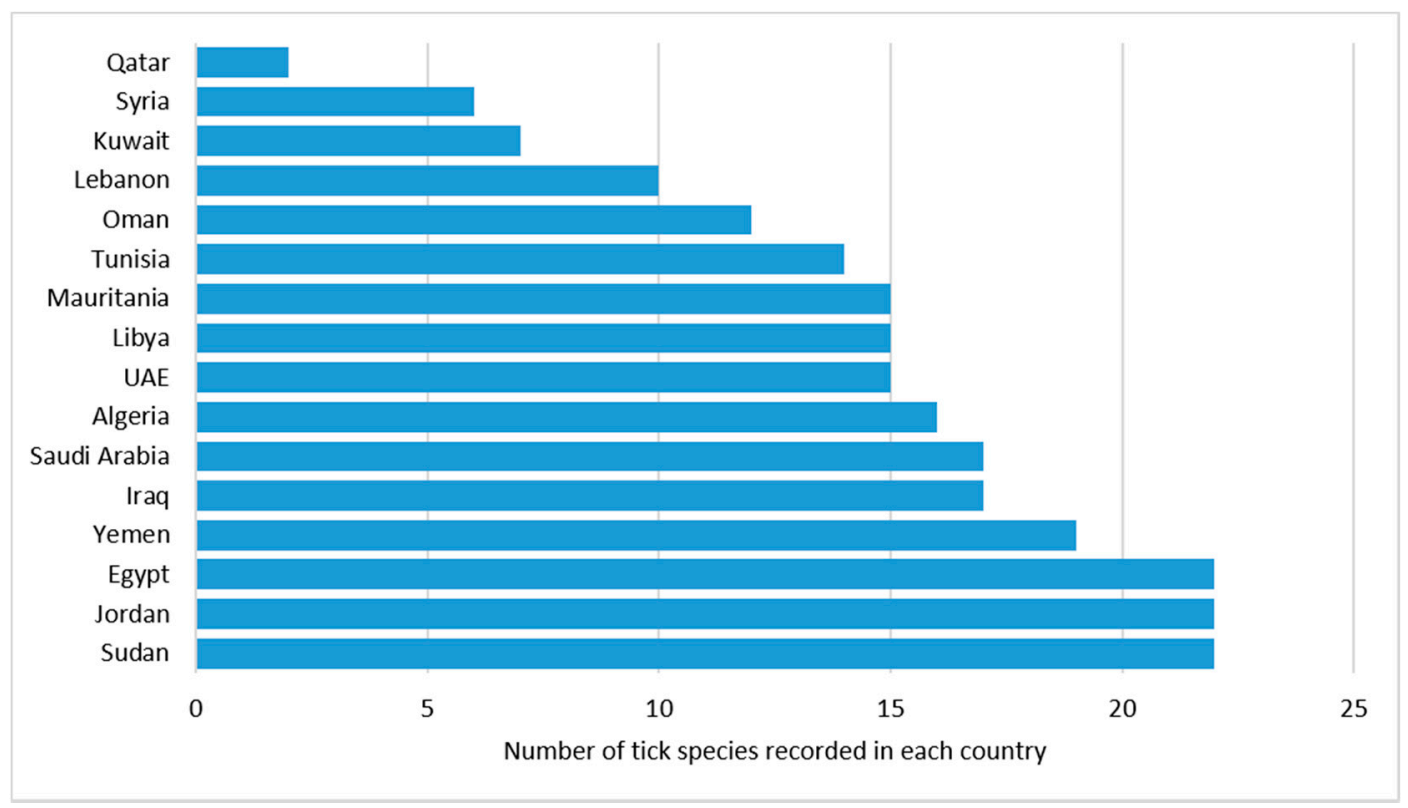

Figure 3. Arab countries with number of tick species reported. Sudan, Jordan, and Egypt have the largest number of reported ticks $(\mathrm{N}=22)$ followed by Yemen, Iraq, and Saudi Arabia $(\mathrm{N}=19,17,17)$, respectively.

\section{Tick-Borne Diseases}

Vector-borne zoonotic diseases have emerged or re-emerged in many geographical regions causing global health and economic problems that involve humans, pathogens, vectors and wildlife $[148,149]$. Many tick-borne diseases such as viral, bacterial, and protozoan have been reported in the Arabian Peninsula. Ticks can be infected with bacteria, viruses or protozoa [23,150-154]. Co-infection of multiple tick-borne pathogens is usually found in dogs [155-157]. Transmission and persistence of vector-borne diseases depend on the overlapping distributions of hosts and vectors combined with the correct set of environmental conditions for a given pathogen $[4,158]$. All these tick-transmitted diseases (including babesiosis, theileriosis, anaplasmosis and cowdriosis) cause important economic losses to the livestock industry, mainly affecting tropical and subtropical countries, where ticks constitute one of the main difficulties for the development of the livestock breeding industry $[23,159]$.

From the medical and veterinarian perspective, most of arthropod-borne infections can be associated with 116 tick species (32 argasid species and 84 ixodids). In addition, tick-borne diseases are common in the medical and veterinary clinical settings and a good surveillance is essential for the management of zoonosis and communicable diseases that are common to humans and animals [160].

In the Arab countries, the ticks that transmit diseases belong to both the soft-tick family, Argasidae (genera Argas, Ornithodoros and Otobius), as well as the hard-tick family, Ixodidae (genera Dermacentor, Hyalomma, Haemaphysalis, Ixodes, Amblyomma and Rhipicephalus) $[41,43,63,98,161,162]$. The main tick-borne diseases of veterinary importance in the tropical countries are theileriosis, babesiosis, cowdriosis and anaplasmosis [66]. However, we documented in this review following major tick-borne diseases of human and animal importance in Arab counties: protozoa diseases (babesiosis and theileriosis), bacterial diseases (anaplasmosis, ehrlichiosis, Lyme borreliosis, Mediterranean spotted fever, spotted fever Rickettsioses, tick-borne relapsing fever and Tularemia), and viral diseases (Alkhurma hemorrhagic fever, Crimean-Congo hemorrhagic fever, and tick-borne encephalitis) (Table 2). The distributions of four widely occurring tick-borne diseases in the MENA region are illustrated in Figure 4. 
Table 2. Tick-borne diseases, pathogens, vectors and hosts in Arab countries.

\begin{tabular}{|c|c|c|c|c|}
\hline Pathogens & Host Species & Tick Vectors & Locality & References \\
\hline CCHFV & Camels, sheep & $\begin{array}{l}\text { H. anatolicum, } \text { H. marginatum } H \text {. rufipes, } \\
\text { H. impeltatum, R. sanguineus, } R \text {. turanicus, } \\
\text { R. annulatus }\end{array}$ & Egypt & [163] \\
\hline CCHFV & Human, livestock & & Egypt & [164] \\
\hline CCHFV & Patients & & United Arab Emirates & [165] \\
\hline CCHFV & Sheep, cattle & H.marginatum & Iraq & [166] \\
\hline CCHFV & Died patient & & United Arab Emirates & [167] \\
\hline CCHFV & Patients & & Kuwait & [168] \\
\hline CCHFV & Patients & & Mauritania & [169] \\
\hline $\mathrm{CCHFV}$ & Patients & & Mauritania & [170] \\
\hline CCHFV & Camel & & Egypt & [171] \\
\hline CCHFV & Livestock & Hyalomma sp. & Oman & [172] \\
\hline CCHFV & Patients & & United Arab Emirates & [173] \\
\hline CCHFV & Camels, cattle, goat & H. impeltatum H. excavatum H. anatolicum & United Arab Emirates & [39] \\
\hline CCHFV & Livestock & Hyalomma sp. & United Arab Emirates & [174] \\
\hline CCHFV & & & Saudi Arabia & [175] \\
\hline CCHFV & Domestic livestock & H. anatolicum, R. evertsi & Oman & [176] \\
\hline CCHFV & Livestock & $\begin{array}{c}\text { A. variegatum, R. decoloratus, R. geigyi, } \\
\text { H. impeltatum, H. impressum, H. rufipes, } \\
\text { H. truncatum, R. guilhoni }\end{array}$ & Mauritania & [65] \\
\hline $\mathrm{CCHFV}$ & Patients & & Sudan & [177] \\
\hline CCHFV & Patients & & Sudan & [178] \\
\hline CCHFV & Livestock & Hyalomma sp. & Iraq & [179] \\
\hline $\mathrm{CCHFV}$ & Patients & & Oman & [180] \\
\hline $\mathrm{CCHFV}$ & Patients & & Sudan & [181] \\
\hline CCHFV & & H. marginatum & $\begin{array}{l}\text { Iraq, UAE, Oman, } \\
\text { Yemen, Saudi Arabia, } \\
\text { Mauritania }\end{array}$ & [182] \\
\hline $\mathrm{CCHFV}$ & Cow & & Egypt & [183] \\
\hline CCHFV & Cattle & & Sudan & [184] \\
\hline CCHFV & $\begin{array}{l}\text { Cattle, camel, } \\
\text { sheep, goat }\end{array}$ & Hyalomma sp. & Oman & [185] \\
\hline CCHFV & Patients & & United Arab Emirates & [186] \\
\hline $\mathrm{CCHFV}$ & Cattle, camel, sheep & & Oman & [185] \\
\hline $\mathrm{CCHFV}$ & Patients & & Mauritania & [187] \\
\hline CCHFV & Patients & & Tunisia & [188] \\
\hline $\mathrm{CCHFV}$ & & & Algeria & [189] \\
\hline CCHFV & Cattle & & Mauritania & [190] \\
\hline CCHFV & Camels & & Sudan & [191] \\
\hline CCHFV & & & Egypt & [192] \\
\hline CCHFV & Humans & & $\begin{array}{l}\text { Iraq, Kuwait, Oman, } \\
\text { Saudi Arabia, Sudan, } \\
\text { UAE }\end{array}$ & [193] \\
\hline
\end{tabular}


Table 2. Cont.

\begin{tabular}{|c|c|c|c|c|}
\hline Pathogens & Host Species & Tick Vectors & Locality & References \\
\hline CCHFV & Livestock & & Egypt, Somalia, Tunisia & [193] \\
\hline CCHFV & Patient & & Oman & [194] \\
\hline $\mathrm{CCHFV}$ & Cattle, camel & H. rufipes, $H$. dromedarii, $H$. impeltatum & Mauritania & [195] \\
\hline CCHFV & Camel & H. dromedarii & United Arab Emirates & [196] \\
\hline ALKV & Patients & & Saudi Arabia & [197] \\
\hline ALKV & Patients & & & [198] \\
\hline ALKV & Patient, dead camel & & Saudi Arabia & {$[197,199]$} \\
\hline ALKV & Camels & O. savignyi & Saudi Arabia & [200] \\
\hline ALKV & Camel, sheep & H. dromedarii & Arabian Peninsula & [201] \\
\hline ALKV & Human & & Egypt & [202] \\
\hline ALKV & Human & & Najran, Saudi Arabia & [203] \\
\hline ALKV & Soldier & & Jazan, Saudi Arabia & [204] \\
\hline TBEV & Human, livestock & I. ricinus & $\begin{array}{l}\text { Europe, North Africa, } \\
\text { Middle East }\end{array}$ & [162] \\
\hline Rickettsia africae & Humans & O. foleyi & Libya & [110] \\
\hline R. africae & Humans & & Mauritania & [205] \\
\hline R. africae & Cattle & $\begin{array}{c}\text { A. variegatum, } R \text {. appendiculatus, } \\
\text { R. microplus }\end{array}$ & Comoros & [206] \\
\hline $\begin{array}{l}\text { Anaplasma. } \\
\text { marginale }\end{array}$ & Cattle & & Libya & [207] \\
\hline A. marginale & Cattle & R. annulatus & Sudan & [208] \\
\hline A. marginale & Cattle, sheep, goat & $\begin{array}{c}\text { R. sanguineus, } R \text {. turanicus, H. excavatum, } \\
\text { H. anatolicum, H. marginatum, } \\
\text { H. turanicum, H. scupense, R. annulatus }\end{array}$ & Iraq & [209] \\
\hline A. ovis & Sheep & Rhipicephalus sp. & Iraq & [75] \\
\hline $\begin{array}{l}\text { A. marginale, } \\
\text { A. central, A. bovis }\end{array}$ & Cattle & & Tunisia & [210] \\
\hline A. marginale & Cattle & & Libya & [211] \\
\hline A. marginale & Buffalo & & Egypt & [212] \\
\hline $\begin{array}{l}\text { Anaplasma sp., } \\
\text { Anaplasma platys }\end{array}$ & Livestock & Rhipicephalus sp., R. sanguineus & Palestine & [213] \\
\hline Rickettsia conorii & & R. sanguineus & Libya & [112] \\
\hline $\begin{array}{l}\text { Ehrlichia } \\
\text { ruminatium }\end{array}$ & Livestock & A. variegatum, A. lepidum & Sudan & [214] \\
\hline Ehrlichia sp. & Livestock & & Egypt & [215] \\
\hline Ehrlichia sp. & Livestock & R. sanguineus & Palestine & [213] \\
\hline Rickettsia sp. & Humans & R.sanguineus & $\begin{array}{l}\text { Algeria, Morocco, } \\
\text { Sudan }\end{array}$ & [216] \\
\hline R. conorii & Humans & & Mauritania & [205] \\
\hline R. conorii & Camels & H. dromedarii & Tunisia & [140] \\
\hline R. conorii & Humans & R. sanguineus & South Jordan & [217] \\
\hline R. aeschlimannii & Livestock & Hyalomma sp. & Egypt & [215] \\
\hline R. aeschlimannii & Cattle, sheep & H. marginatum, H. scupense & Algeria & [59] \\
\hline
\end{tabular}


Table 2. Cont.

\begin{tabular}{|c|c|c|c|c|}
\hline Pathogens & Host Species & Tick Vectors & Locality & References \\
\hline $\begin{array}{c}\text { R. conorii, } \\
\text { R. aeschlimannii }\end{array}$ & Camels & H. dromedarii & Tunisia & [140] \\
\hline Rickettsia sp. & Camels & H. dromedarii & UAE & [143] \\
\hline Coxiella burnetii & Humans & & Libya & [218] \\
\hline C. burnetii & Humans & & Mauritania & [205] \\
\hline $\begin{array}{l}\text { Borrelia } \\
\text { burgdorferi, } \\
\text { B. lusitaniae, } \\
\text { B. garinii }\end{array}$ & & I. ricinus & Tunisia & [137] \\
\hline B. burgdorferi & Humans & I. scapularis & Egypt & {$[219]$} \\
\hline B. burgdorferi & Humans & & Egypt & [220] \\
\hline B. burgdorferi & Human, livestock & I. ricinus & $\begin{array}{l}\text { Europe, North Africa, } \\
\text { Middle East }\end{array}$ & [162] \\
\hline \multirow[t]{2}{*}{ Borrelia sp. } & Humans & Ornithodoros sp. & Sudan & [221] \\
\hline & Humans & O. tholozani & Libya & [111] \\
\hline Borrelia sp. & Humans & Ornithodoros sp. & Egypt & [37] \\
\hline Borrelia sp. & Humans & O. tholozani & Jordan & {$[98]$} \\
\hline Borrelia persica & Livestock & O. tholozani & Syria, Egypt & [222] \\
\hline Borrelia sp. & & Ornithodoros sp. & $\begin{array}{l}\text { Iraq, Syria, Jordan, } \\
\text { Egypt }\end{array}$ & [223] \\
\hline $\begin{array}{l}\text { Francisella } \\
\text { tularensis }\end{array}$ & Human & & Egypt & [224] \\
\hline F. tularensis & Human & & Iraq, Syria & [225] \\
\hline F. tularensis & Human & & Syria, Egypt, Lebanon & [226] \\
\hline Francisella spp. & Camel & H. dromedarii & Egypt & [227] \\
\hline Francisella sp. & Camel & H. dromedarii & United Arab Emirates & [228] \\
\hline $\begin{array}{c}\text { Babesia bigemmina, } \\
\text { B. ovis }\end{array}$ & Camel, cows, sheep & $\begin{array}{c}\text { Hyalomma sp., Boophilus sp., } \\
\text { Rhipicephalus sp., Amblyomma sp., } \\
\text { Argas sp. }\end{array}$ & Egypt & [41] \\
\hline B.bigemina & Cattle & & Libya & [207] \\
\hline $\begin{array}{l}\text { B. bovis, } \\
\text { B. bigemina }\end{array}$ & Cattle & $\begin{array}{c}\text { R. annulatus, I. ricinus, H. punctata, } \\
\text { H. sulcata, H.excavatum, H. scupense, } \\
\text { H. marginatum }\end{array}$ & Tunisia & [141] \\
\hline Babesia spp. & Livestock & H. scupense, R. bursa & Tunisia & [139] \\
\hline $\begin{array}{l}\text { B. bigemina, } \\
\text { B. bovis }\end{array}$ & Cattle & R. annulatus & Sudan & [208] \\
\hline B. occultans & & H. marginatum & Tunisia & [136] \\
\hline Babesia sp. & Cattle & H. anatolicum & Iraq & [229] \\
\hline B. bigemina & Cattle, sheep, goat & $\begin{array}{c}\text { R. sanguineus, } R \text {. turanicus, } \text { H. excavatum, } \\
\text { H. anatolicum, H. marginatum, } \\
\text { H. turanicum, H. scupense, R. annulatus }\end{array}$ & Iraq & [209] \\
\hline B. ovis & Sheep & Rhipicephalus sp. & Iraq & [75] \\
\hline Babesia sp. & Camel & & Saudi Arabia & [230] \\
\hline
\end{tabular}


Table 2. Cont.

\begin{tabular}{|c|c|c|c|c|}
\hline Pathogens & Host Species & Tick Vectors & Locality & References \\
\hline $\begin{array}{l}\text { B. ovis, B. motasi, } \\
\text { B. foliate B.taylori }\end{array}$ & Sheep, goat & H. anatolicum & Iraq & [231] \\
\hline Babesia sp. & Camel, cow & O. savignyi, R. annulatus & Egypt & {$[61]$} \\
\hline Theileria annulata & Calf & H. anatolicum & Bahrain & [232] \\
\hline T. annulata & Cow & H. dromedarii & Mauritania & [233] \\
\hline $\begin{array}{l}\text { T. annulata, T. ovis, } \\
\text { T. hirci }\end{array}$ & Camel, Sheep, goat & Ixodid sp. & Saudi Arabia & [121] \\
\hline T. annulata & & H. dromedarii & Mauritania & [234] \\
\hline T. annulata & $\begin{array}{l}\text { Camels, cows, } \\
\text { sheep }\end{array}$ & $\begin{array}{l}\text { Hyalomma sp., Rhipicephalus sp., } \\
\text { Amblyomma sp., Argas sp. }\end{array}$ & Egypt & [41] \\
\hline T. lestoquardi & Sheep & H. anatolicum & Oman & [235] \\
\hline T. mutans & Cattle & & Libya & [207] \\
\hline $\begin{array}{l}\text { T. annulata, } \\
\text { T. buffeli }\end{array}$ & Cattle & $\begin{array}{c}\text { R. annulatus, I. ricinus, } \text { H. scupense, } \\
\text { H. sulcata, H. punctata, H.excavatum, } \\
\text { H. marginatum }\end{array}$ & Tunisia & [141] \\
\hline T. annulata & Cattle & Hyalomma sp. & Iraq & [236] \\
\hline Theileria spp. & Livestock & H. scupense, R. bursa & Tunisia & [139] \\
\hline T. lestoquardi & Sheep & & Oman & [237] \\
\hline Theileria sp. & Cattle & H. anatolicum & Iraq & [229] \\
\hline $\begin{array}{l}\text { T. ovis, } \\
\text { T. lestoquardi, } \\
\text { T. uilenbergi }\end{array}$ & Sheep & Rhipicephalus sp. & Iraq & [75] \\
\hline $\begin{array}{l}\text { T. ovis, T. annulata, } \\
\text { T. lestoquardi }\end{array}$ & Sheep & Ixodes sp. & Iraq & [161] \\
\hline T. annulata & Camel & H. dromedarii & Egypt & [43] \\
\hline T. annulata & Camel & H. dromedarii & United Arab Emirates & [143] \\
\hline T. annulata & Cattle & & Oman & [238] \\
\hline $\begin{array}{l}\text { T. annulata, T. ovis, } \\
\text { T. lestoquardi }\end{array}$ & Cattle, sheep, goat & H. anatolicum & Oman & [239] \\
\hline T. annulata & Camel & H. dromedarii & Egypt & [43] \\
\hline
\end{tabular}

$\mathrm{CCHFV}=$ Crimean-Congo hemorrhagic fever virus, ALKV = Alkhumra virus, TBEV = tick-borne encephalitis virus.

\subsection{Viral Diseases}

\subsubsection{Alkhurma Hemorrhagic Fever Virus (ALKV)}

This virus is a recently described member of the tick-borne hemorrhagic fever group of the genus Flavivirus. Camels and sheep are thought to be the natural hosts of ALKV [202]. ALKV was recently detected in an O. savignyi tick collected near Jeddah, Saudi Arabia [200]. In the Arabian Peninsula, these ticks have been associated with camels and their resting places and can be found where cases of ALKV infection in humans have been reported. Overall, Alkhurma virus was reported from Egypt [202] and Saudi Arabia [197,198,203,204,240] (Table 2). 

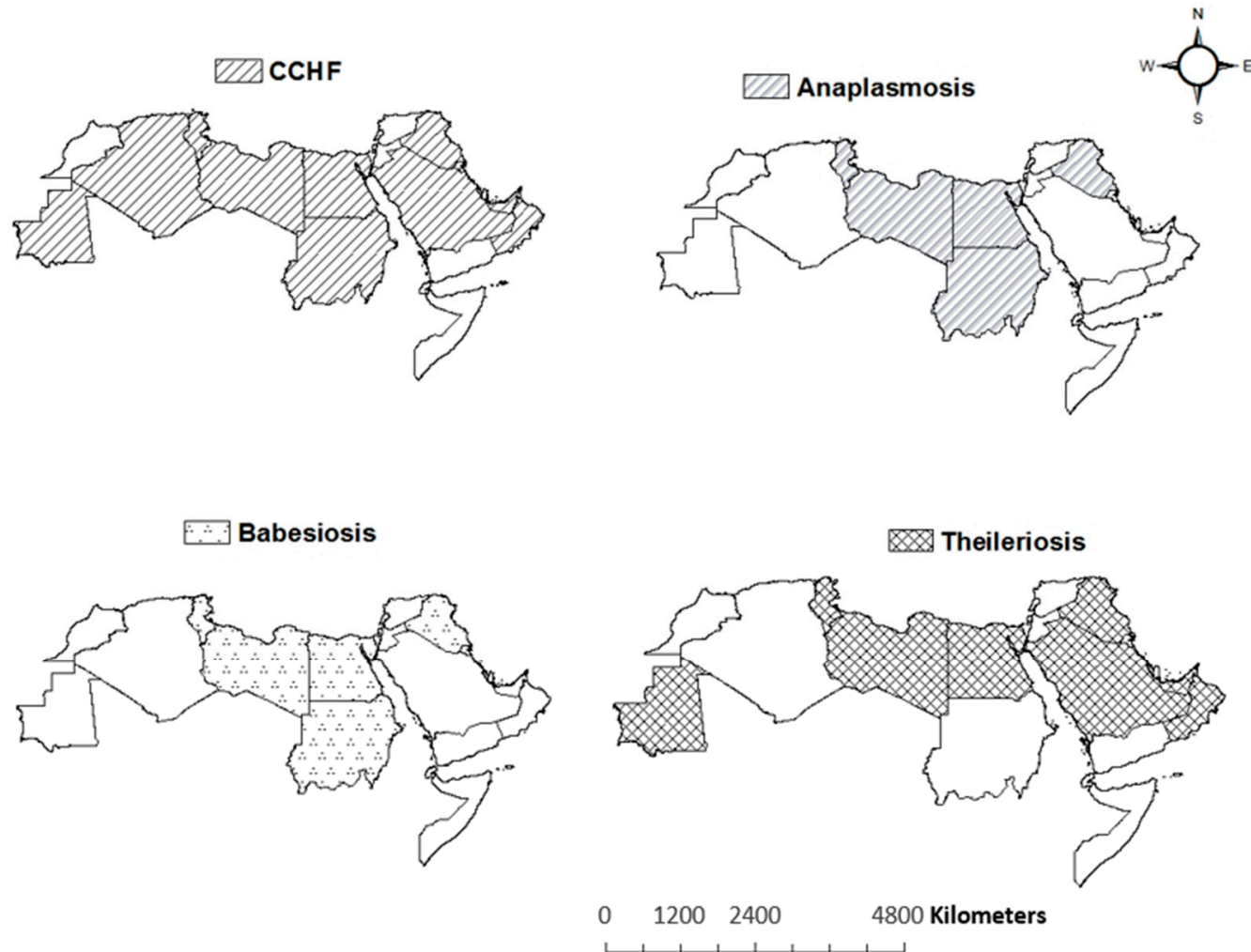

Figure 4. The geographic distribution of tick-borne diseases (CCHF, Anaplasmosis, Babesiosis and Theileriosis) in Arab countries.

\subsubsection{Crimean-Congo Hemorrhagic Fever (CCHF)}

$\mathrm{CCHF}$ has been reported from more than 30 countries in Africa, Asia, South-East Europe, and the Middle East. The majority of human cases are workers in livestock industry, agriculture, slaughterhouses, and veterinary practice [241,242]. The infection of CCHF is enzootic, however, mostly asymptomatic in many animal species such as cattle, sheep, goats, and camels $[173,243]$. Thirty species of ticks, particularly the genus Hyalomma, act as both reservoir and vector for this pathogen. Humans become infected by tick bites or through close contact with infected animals and humans [242]. Hyalomma ticks were responsible for outbreaks in humans with high fatalities in the UAE, Oman, and Saudi Arabia [165,172]. CCHF virus survives trans-stadially (from larva to nymph to adult) and inter-seasonally in several tick species and is transmitted transovarially to the F1 generation (in some cases to F2) in H. marginatum, H. rufipes, D. marginatus and Rhipicephalus rossicus [164]. CCHF disease causing virus has been reported from almost all countries of Arabian Peninsula (Table 2) [163,166,172,174,176,180,182-184,188,189,193].

\subsubsection{Tick-Borne Encephalitis (TBE)}

This vector-borne disease is caused by the tick-borne encephalitis virus (TBEV) which belongs to Flavivirus genus, and has been a growing public health concern in Europe and other parts of the world for the past 20 years [244]. Ticks are considered both vectors and reservoirs for TBEV [245], humans can also acquire TBE infections by consuming unpasteurized milk and cheese [246]. TBEV, the causative agent, is transmitted to humans through the bite of an infected vector tick (I. ricinus or I. persulcatus). The vertebrate hosts of I. ricinus and I. persulcatus, which may have TBEV, are wild and domestic animals. The virus prevalence in ticks can vary substantially within and among risk areas [244]. Various species of mammals and migratory birds also play an important role in the transmission and distribution of TBEV [247]. TBE cases have been reported from Saudi Arabia in 1995 [248]. To date, no causal treatment is known, however, infection and disease can 
be prevented by avoiding tick bites (using insect repellents, etc.) and vaccination [244]. Therefore, this could be emerging disease in Arab world or Middle East.

\subsection{Bacterial Diseases}

\subsubsection{Anaplasmosis}

It occurs in tropical and subtropical areas throughout the world and the disease is a major constraint to cattle production in many countries [249]. Anaplasmosis is a widely spread tick-borne infection of humans and animals, caused by Anaplasma species including A. marginale, A. centrale, A. bovis, and A. ovis for ruminants, and A. phagocytophilum for human and domestic animals [250]. The disease in humans is called 'Human Granulocytic Anaplasmosis' [251] and in cattle is called bovine anaplasmosis [249]. Belkahia et al. [210] reported three Anaplasma species including A. marginale, A. centrale, and A. bovis, from Tunisian cattle. Whereas, Awad et al. [208] reported A. marginale in cattle in northern Sudan and $R$. annulatus was the vector. Anaplasmosis has also been reported from other countries including Libya, Egypt, Iraq and Palestine (Table 2) [75,212,213].

\subsubsection{Ehrlichiosis}

This tick-borne disease has been detected from both humans and animals. In humans, ehrlichiosis is called 'human monocytotropic ehrlichiosis' and caused by A. phagocytophilum, Ehrlichia chaffeesis, and Ehrlichia ewingii. The diseases are transmitted by ixodid ticks [250]. Ehrlichiosis is reported from Egypt, Palestine and Sudan (Table 2) [213-215].

\subsubsection{Mediterranean Spotted Fever (MSF)}

Mediterranean spotted fever is a tick-borne disease caused by Rickettsia conorii. It was first described a century ago as a disease associated with high fever and spots. Conor and Bruch [252] first described the disease in Tunisia in 1910, and it was soon reported in other regions around the Mediterranean basin. R. conorii is an obligate intracellular, Gram-negative bacterium that is extremely fastidious [252]. R. sanguineus is the main vector of the disease. Humans are an accidental host of Rickettsia, and they have no role in maintaining this bacterium in nature [217]. The bacterium can affect people of all ages. Mediterranean spotted fever has been reported from Arab countries including Algeria, Morocco, Sudan, Jordan, Mauritania and Tunisia (Table 2) [140,205,216,217].

\subsubsection{Spotted Fever Rickettsioses (SFR)}

Spotted fever Rickettsioses is an important tick-borne disease group in animals and humans in the world. SFR includes rocky mountain spotted fever (RMSF), Pacific Coast tick fever, and Rickettsial pox. The Rickettsial pathogens are categorized into order Rickettsiales, which includes the family Rickettsiaceae and Anaplasmataceae [253,254]. Most of the rickettsial diseases are caused by infection with obligate intracellular Gram-negative bacteria transmitted by arthropod vectors [252,255]. Al-Deeb et al. [143] recorded spotted fever group Rickettsia sp. in H. dromedarii ticks in the UAE. In addition, Demoncheaux et al. [140] reported Rickettsia aeschlimannii in H. dromedarii ticks from Tunisia [140] and Loftis et al. [215] detected R. aeschlimannii in Hyalomma sp. from Egypt [215].

\subsubsection{Tick-Borne Lyme Borreliosis}

This is a zoonotic disease transmitted by hard ticks of the genus Ixodes [256,257] and most common in temperate forested regions of North America, Europe and Asia [258]. Globally, Lyme disease is caused by some members of the B. burgdorferi sensu lato (s.l.) species complex including B. burgdorferi sensu stricto in North America [259] and five species in Europe, Borrelia afzelii, B. garinii, B. burgdorferi, Borrelia spielmanii and Borrelia bavariensis [260]. Nymphs of I. scapularis ticks transmit B. burgdorferi to humans far more frequently than adult ticks. Efficient transmission of this spirochete requires a minimum of 24 to $48 \mathrm{~h}$ of tick attachment, at which time the nymph obviously is engorged with blood [261]. There are tens of thousands of clinical cases of Lyme disease reported annually. 
However, with the estimation of underreporting, there are hundreds of thousands of infections each year [258]. Developing novel control methods and predicting disease risk to better target control interventions require understanding pathogen and disease dynamics [258]. Various pathogens such as B. burgdorferi, B. lusitaniae, B. garinii were reported in I. ricinus from Tunisia [137]. However, B. burgdorferi was detected in ixodid ticks (R. annulatus, H. dromedarii, H. excavatum and R. sanguineus) and soft ticks (O. savignyi) from Egypt in 2010 and 2014 [219,220] and in I. ricinus from other Middle East and North African countries [162] (Table 2).

\subsubsection{Tick-Borne Relapsing Fever (TBRF)}

Relapsing fever cases were reported from Sudan in 1939 [221], from Egypt in 1954 [37] and from Jordan in 1957 in humans [98]. TBRF is attributed mainly to spirochete Borrelia. Ornithodoros is the most important tick vector, found in Iraq, Syria, Jordan, and Egypt [223]. However, a louse-borne relapsing fever outbreak in Sudan was estimated to have affected 20,000 members of the Dinka tribe in 1998 and 1999; the death rate was 10-14\% [262]. Reports of tick-borne relapsing fever appear to be involved in clusters of infection, associated with exposure of susceptible human hosts to tick vectors and domestic animals. In the Middle East, B. persica infections were transmitted by O. tholozani vector, in 2005 [262].

\subsubsection{Tularemia}

This is a zoonotic disease that is caused by the gram-negative bacterium F. tularensis $[263,264]$. Ticks play important role in the epidemiology of Tularemia as a reservoir and vector, and can carry the bacterium by both of trans-ovarial and trans-stadial transmission [226]. Amblyoma, Dermocentor and Ixodes species are considered the main vector responsible for transmission [226]. In Arab countries, recently genus Francisella is reported in H. dromedarii from Egypt [227] and UAE [228]. Further, the presence of F. tularensis IgG antibodies in some patients in Egypt [227] poses a serious threat about emergence and re-emergence of Tularemia due to high prevalence of tick species in Arab world $[142,144]$.

\subsection{Protozoal Diseases}

\subsubsection{Babesiosis}

This is a zoonotic infection of animals and humans, caused by Babesia spp., and transovarially and trans-stadially transmitted by Ixodid ticks [265]. The disease is characterized by high temperature, anemia, restlessness, anorexia, and death. Babesiosis is seen in domestic animals, including sheep and goats, however the major economic impact of this infection is on the livestock industry worldwide due to high losses [231,250,266]. Babesiosis was investigated in blood samples of sheep and goats in Kurdistan-Iraq from June to September 2012 and four Babesia species were detected: B. ovis, B. motasi, B. foliata, and B. taylori. One species of tick vector H. anatolicum was found on these animals [231]. Babesia spp. have also been reported from Egypt, Libya, Tunisia, Iraq, Sudan, Saudi Arabia [61,75,207,208,229,230] (Table 2).

\subsubsection{Theileriosis}

This is one of the most common tick-borne diseases, which have been studied in a wide range of livestock such as cattle, sheep, and goats. Few people studied theileriosis infected camels $[41,43,267]$. Theileriosis is caused by Theileria (obligate intracellular protozoan parasites) transmitted by ixodid ticks (Hyalomma spp.), which yields severe and mild infections in their vertebrate hosts [43]. This pathogen (Theileria spp.) has been described in all livestock species and can cause significant economic losses to farmers [268]. Theileria sp. has been reported from most of countries in Arab region including Egypt, Sudan, UAE, Mauritania, Saudi Arabia, Oman, Libya, Tunisia and Iraq [43,75,121,141,143,207,229,238] (Table 2). 


\section{Ticks and Livestock Industry}

Ticks are presented with a unique set of challenges and opportunities in the Arab region. The natural environment is arid and inhospitable, with pockets of habitat that periodically become productive [24]. This is a challenge for the survival of hosts and therefore also for ticks. However, the widespread occurrence of livestock in the region, presents ticks with the opportunity to thrive in high densities in artificially improved conditions (e.g., with shelter and water provided for animals). Although there have been efforts to modernize the livestock industry, local farms with low to medium density of livestock abound in the region. These farms have frequent input of imported livestock since cattle, sheep and goats are regularly imported into the MENA region from Australia, New Zealand, China and Argentina [269]. Local populations of ticks, therefore, have opportunities to feed on naïve hosts from outside the region, with substantial chances of boosting populations to levels much higher than what could be normally supported in an arid environment. Thus, ticks have been enhanced in the region and farms represent areas of high population density and evolution of ticks. Specifically, the use of acaricides is widespread and without any form of vector control [270]. Thus, ticks have the continuous opportunity to develop resistance to acaricides [270,271]. Frequent influx of foreign host animals also raises the chance of importing pathogens, especially those that may remain dormant in the host [272]. This is discussed further in the following section.

\section{Infectious Diseases and Global Movement of Humans and Domestic Animals}

With the development of effective vaccines, antibiotics and improved sanitation, infectious diseases were significantly reduced in the developed world in 1970s. However, the emergence of a series of new diseases and global spread of HIV / AIDS, led to infectious diseases being considered with increasing priority in health policy and political agendas [273,274]. More than $60 \%$ of human infectious diseases emerging between 1940 and 2004 were zoonotic, resulting in significant global morbidity, mortality, and economic costs [275]. Of those emerging zoonoses, $71.8 \%$ are from wildlife and $22.8 \%$ are arthropod vector-borne infections [275]. Significantly, the frequency of emerging vector-borne zoonoses has increased during the last ten years [275,276]. Public concern about emerging infectious diseases was increased because of their often rapid spread and high case fatality rates $[277,278]$. Infectious diseases emergence was associated with environmental or human behavioral change and human interaction with wildlife [279]. Emergence was found to be intensified by increasing human travel and globalized trade [280]. New infectious diseases continued to emerge, often from unexpected reservoirs and via new pathways [4].

Travel, trade and an altered attitude towards domestic animals, wildlife and nature influence vectors and pathogens distribution worldwide. The Middle East imports mostly goats, sheep and cattle from as far as Australia, China and Argentina, often using mixed transportation systems [269]. Mixed transportation often results in considerable morbidity and mortality of livestock. However, surviving livestock can serve as a source for nonnative tick species that could help to import non-native pathogens. Furthermore, increased tick densities could permit non-native pathogens to enter and maintain circulation within farming systems. The fundamental problem and trigger for these effects, however, seems due to the increased human population size and associated farming activities [281]. There are multiple causes of novel disease emergence; however the human-mediated transport of pathogens or vectors across geographical or ecological boundaries (pathogen pollution) has been identified as a major driver of diseases emergence in animals [4]. Therefore, it is very likely that tick-borne diseases will remain within farming systems and will become an increasing problem [281].

There are some scattered reports in the literature of Hyalomma species being imported into the USA, most-commonly on animals and animal products. Mertins and Schlater [282] documented five species of Hyalomma on ostriches imported from Africa and Europe. However, Keirans and Durden [283] reported one case of H. marginatum found on a human 
with travel history to Greece. A detailed travel history may be important for identification of ticks, as well as to assess the risk of vector-borne diseases.

Hyalomma is one of the most medically-important tick genera in the region. Species in this genus have been reported to transmit a variety of viral, bacterial, and parasitic diseases of medical and veterinary importance [27]. One of the most crucial human viruses transmitted by Hyalomma spp. is CCHF virus. Sexually and transovarial transmission of CCHF virus was observed experimentally in H. truncatum [284]. In fact, comprehensive documents and research papers exist showing that several tick species transmit the bacteria, virus and parasites in different geographical areas of the world [285]. For instance, H. marginatum transmitted the CCHF in Russia, Turkey, and Crimean Peninsulas, H. anatolicum in Iran, Pakistan, Turkmenistan, and Tajikistan, H. asiaticum from Central Asia to China, and H. rufipes in Africa $[27,286,287]$. Other important disease agents of humans and their documented vectors include $R$. conorii in $H$. rufipes and $H$. truncatum, $R$. aeschlimannii in $H$. marginatum, $H$. truncatum, and $H$. scupense, $R$. sibirica in $H$. asiaticum, $H$. excavatum, and H. truncatum, A. phagocytophilum in H. lusitanicum, and C. burnetii in H. scupense $[27,287,288]$. Hyalomma species have also been implicated in tick paralysis in humans [289].

Thousands of livestock are imported annually from Arabian countries such as Sudan, Somalia and others such as Turkey, Argentina, Pakistan, Australia Iran and Uruguay in Saudi Arabia and UAE. Camel, sheep, goat and cattle production plays an integral part in the agricultural sector and contribute significantly to the food security of the country [11]. Prior to 1995, tick records from the UAE were limited. Records on file at the U.S. National Tick Museum indicate that only the ixodid ticks, H. anatolicum, H. impeltatum, H. dromedarii, $R$. sanguineus, and $R$. turanicus, were reported in the UAE before CCHF outbreak in UAE 1994-1995 [39]. Ticks collected during this CCHF outbreak investigation represent the largest group of ticks collected to date from the UAE and indicate that several competent vectors of CCHF virus were being imported [39]. Results of this investigation indicated that most $\mathrm{CCHF}$ virus-infected animals were imported from Somalia, with fewer numbers of infected animals possibly arriving from Iran [39].

Little efforts have been made to put in place the policies to reduce risk. Determining and preventing the importation of infected hosts is widely used to stop importation of many domestic animal diseases of economic or public health importance. Some countries even endorse this principle for the movement of people, whereby they conduct surveillance for infected persons arriving at their international borders, particularly during human pandemics. The World Health Organization (WHO) provides guidance and training through its international health regulations (IHR). Rules and regulations for international trade including animals and their products are created and enforced by the WHO, for smooth flow of trade [4].

\section{Climate Change and Ticks and Tick-Borne Diseases}

Like the rest of the world, Arab countries are affected by climate change. Climate change is considered one of the many factors that play a role in tick abundance and distribution. Climate change impact (positive or negative) on the biology of ticks (e.g., higher mean temperatures and increased humidity facilitate tick survival on certain latitudes, in other regions the opposite effect occurs). Other factors such as habitat fragmentations, demographic modifications and other environmental changes may also be involved and complicating the processes. These factors may also facilitate the survival and establishment of colonies in regions where tick species were not prevalent before [290]. The knowledge regarding the disease causing pathogens and their epidemiology have significantly improved during the last decade, further studies are required to explain the lifecycle of these pathogens, (viruses, bacteria and protozoa) antigenic differences and human immune response for effective treatment and vaccine development [281]. Developing novel control methods and predicting disease risk to better target control interventions require understanding of pathogen and disease dynamics [258]. Meanwhile, the best way for pre- 
vention of the disease is the education of risk groups (especially farm labors and workers at slaughter houses/abattoir) and awareness in healthcare workers.

The distribution and abundance of tick populations also depend on the interaction of large-scale climate influences, local scale microclimates, habitat characteristics (including tick predators) and host densities [258]. Microclimate conditions may impact tick survival directly by increasing tick mortality rates, and indirectly by influencing the activity [291,292]. Both cold and hot temperatures significantly decrease the tick survival and host-seeking activity. Low humidity reduces activity and can kill ticks quickly through desiccation; high levels of rainfall also inhibit activity [293]. In adverse climate conditions, ticks often seek microclimate refuges in leaf litter or debris to reduce the impacts of extreme temperature and humidity on survival [294]. The risk of human infection thus is thought to increase with the density of questing infected nymphs in the environment, which is the product of the density of nymphs and their infection prevalence, and varies at a very local scale [258].

\section{Strategies for Prevention and Control of Infectious Diseases}

One health approach is used to tackle the zoonotic diseases by considering all components including environmental and ecological/wildlife as well as domestic animal and human factors (cultural, political and other socio-economic drivers) [1]. The success of this multi-disciplinary approach has been driven by combining the field sciences with analytical approaches and laboratory science. Challenges remain, however. Disease control or prevention is best achieved through integrated public health, veterinary medicine, animal management and ecological approaches. Health approaches are also mandatory at the policy and governance levels and these become successful and cost-effective if developed and implemented by all relevant parties including ecologists, conservation biologists, policy-makers and experts from veterinary and medical professions [4].

\section{General Recommendations}

\subsection{Lack of Publication Record in Arab Countries}

We found no published research papers on ticks and tick-borne pathogens in some Arab countries, despite the presence of animals in them. This could be interpreted in two ways. One possibility is that there might be no tick infestations in the country, which is very unlikely, knowing how prevalent the ticks are in the region. The second possibility might be that there is no research done on ticks, which could be the result of having different problems that need to be investigated and fixed. Whatever the case might be concerned authorities in each country should encourage tick-related research and provide necessary resources especially financial support.

\subsection{Need of Mutual Collaboration}

According to published papers, some tick species were common in neighboring countries that share joint borders. This calls for mutual collaboration among such countries to study and stop tick cross-border movement. In addition, the success of any tick control program in one country is always going to be reliant on good collaboration from the country on the other side of the border. Otherwise, it will serve as a tick reservoir from which ticks continue to cross into the border and reestablish infestations.

In order to enhance tick control efforts, inter-country research projects should be established and supported by inter-country funding. This is very important for the management of tick species that are common in more than one country. Moreover, establishing a central collection of tick specimens and a repository for DNA and RNA samples extracted from different tick species in each country can facilitate and enhance the research on ticks. Consequently, tick management will be more successful over time. In addition, the collaboration among research teams in different countries will be more successful and effective. 


\subsection{Need to Create Awareness through Workshops and Conferences}

It is important to organize awareness creation workshops to ensure that the reporting of ticks and tick-borne pathogens is going to be a routine practice for people dealing with animals and that this is always going to be done in a proper and timely manner. This is because some animal care providers do not fully appreciate the importance of publishing research results or reporting the presence of tick and tick-borne pathogens as long as proper medicine and treatment are given to affected animals.

\subsection{Animal Trade (Import and Export) Regulations}

Animal trade (import and export) regulations concerning border inspections of animals for the presence of ticks and tick-borne pathogens should be standardized among all Arab countries. This practice can eliminate, or at least minimize, any infiltration of ticks into a new country as a result of lenient inspection on some points of entry.

\subsection{Tick Surveillances Programs}

There is a need for conducting comprehensive tick surveillances (qualitative and quantitative) in each Arab country in order to know tick species and hosts. The results should be coupled with tick species mapping to determine the geographical distribution of tick infestations and the hot spots in each country. Latest mapping software and global positioning system data should be utilized.

\subsection{Reference Laboratory}

It is vital to establish a standard reference laboratory in each Arab country to identify tick-borne pathogens and to serve as an information resource and point of contact at the national, regional, and international levels.

\subsection{Cutting-Edge Research Protocols}

There is a need to encourage the use of cutting-edge research protocols for studying and identifying ticks and tick-borne pathogens with an emphasis on the use of molecular tools and next generation sequencing.

\section{Conclusions}

Because the ixodid tick species reported in this review infests both animals and humans, they have veterinary and medical importance. The increase in tick-borne diseases has been attributed to a range of factors that include habitat fragmentation, changes in host communities, human travel and trade, and climate change. The ending of critical gaps in tick-borne diseases ecology research would significantly improve our ability to forecast the location and timing of hot spots of these infectious diseases and to target control efforts at the most important phase of the transmission cycle. Efficient prevention and control require the understanding of the local ecology and human behavior.

Author Contributions: Conceptualization, M.A.A.-D. and S.B.M.; methodology, M.A.A.-D. and S.B.M.; investigation, N.P.; writing—original draft preparation, N.P., S.B.M., and M.A.A.-D.; writingreview and editing, N.P., S.B.M., and M.A.A.-D.; visualization, N.P.; project administration, M.A.A.-D.; funding acquisition, M.A.A.-D. and S.B.M. All authors have read and agreed to the published version of the manuscript.

Funding: The funding of this study was provided by the UAE University through UPAR grant \#G00002604.

Institutional Review Board Statement: Not applicable.

Informed Consent Statement: Not applicable.

Acknowledgments: We thank Remya Kottarathu Kalarikkal for assistance in preparing maps.

Conflicts of Interest: The authors have no competing interests to declare. 


\section{References}

1. Daszak, P.; Cunningham, A.A.; Hyatt, A.D. Emerging infectious diseases of wildlife-Threats to biodiversity and human health. Science 2000, 287, 443-449. [CrossRef]

2. Wilcox, B.A.; Colwell, R.R. Emerging and reemerging infectious diseases: Biocomplexity as an interdisciplinary paradigm. Ecohealth 2005, 2, 244-257. [CrossRef]

3. Muzaffar, S. Diseases and Parasites of Birds: Ecology and Epidemiology in a Changing World. Ph.D. Thesis, Department of Biology Memorial, University of Newfoundland, St. John's, NL, Canada, 2007.

4. Cunningham, A.A.; Daszak, P.; Wood, J.L.N.; Cunningham, A.A. One Health, emerging infectious diseases and wildlife: Two decades of progress? Philos. Trans. R. Soc. B 2017, 372, 1-8. [CrossRef] [PubMed]

5. Epstein, P.R. Climate Change and Emerging Infectious Diseases. Microbes Infect. 2001, 3, 747-754. [CrossRef]

6. Daszak, P. Emerging infectious diseases and the socio-ecological dimension. Ecohealth 2005, 2, 239-240. [CrossRef]

7. Faour-klingbeil, D.; Todd, E.C.D. A Review on the Rising Prevalence of International Standards: Threats or Opportunities for the Agri-Food Produce Sector in Developing Countries, with a Focus on Examples from the MENA Region. Foods $2018,7,33$. [CrossRef]

8. Hasson, R.H.; Al-Zubaidi, H.H. Cattle and buffaloes tick's infestation in Wasit province districts, Iraq. Kufa J. Vet. Med. Sci. 2014, 5, 31-40.

9. FAO. Livestock Systems. 2020. Available online: http://www.fao.org/livestock-systems/en/ (accessed on 17 August 2020).

10. Montiel-Parra, G.; Fuentes-Moreno, H.; Vargas-Sandoval, M. Primer registro de Ixodes cookei (Acari: Ixodidae) para México. Rev. Mex. Biodivers. 2007, 78, 205-206.

11. Alanazi, A.D.; Alyousif, M.S.; Puschendorf, R. Ticks (Acari: Ixodidae) Infesting Domestic and Wild Mammalians on the Riyadh Province, Saudi Arabia. J. Entomol. 2018, 15, 75-82. [CrossRef]

12. Al-khalifa, M.S.; Diab, F.M.; Khalil, G.M. Man-threatening viruses isolated from ticks in Saudi Arabia. Saudi Med. J. 2007, 28, 1864-1867.

13. ElGhali, A.; Hassan, S.M. Ticks (Acari: Ixodidae) infesting camels (Camelus dromedarius) in Northern Sudan. J. Vet. Res. 2009, 76, 177-185. [CrossRef] [PubMed]

14. Guglielmone, A.A.; Robbins, R.G.; Apanaskevich, D.A.; Petney, T.N.; Estrada-Peña, A.; Horak, I.G.; Shao, R.; Barker, S.C. The Argasidae, Ixodidae and Nuttalliellidae (Acari: Ixodida) of the world: A list of valid species names. Zootaxa 2010, 2528, 1-28. [CrossRef]

15. Tadmouri, G.O. The Arab world. Genet. Disord. Arab World United Arab Emirates. 2004; pp. 1-5. Available online: https: / / www.cags.org.ae/cbc01ar.pdf (accessed on 17 August 2020).

16. Elasha, B.O. Mapping Climate Change Threats and Human Development Impacts in the Arab Region; United Nations Development Pro-Gramme: New York, NY, USA, 2010; p. 51.

17. Anonymous. Total Population-Arab World. Arab World Data. 2020. Available online: https//data.worldbank.org/country/1A (accessed on 19 September 2020).

18. Abahussain, A.A.; Abdu, A.S.; Al-Zubari, W.K.; El-Deen, N.A.; Abdul-Raheem, M. Desertification in the Arab Region: Analysis of current status and trends. J. Arid Environ. 2002, 51, 521-545. [CrossRef]

19. Khan, Z.I. The Arab World-An Arab perspective. Milli Gaz. Delhi, India. 2013; p. 16. Available online: https//www.milligazette. $\mathrm{com} /$ news / 8-international/6666-the-arab-world-an-arab-perspective/ (accessed on 17 August 2020).

20. Champour, M.; Chinikar, S.; Mohammadi, G. Molecular epidemiology of Crimean-Congo hemorrhagic fever virus detected from ticks of one humped camels (Camelus dromedarius) population in northeastern Iran. J. Parasit. Dis. 2016, 40, 110-115. [CrossRef] [PubMed]

21. Pasalary, M.; Arbabi, M.; Pashei, S.; Abdigoudarzi, M. Fauna of ticks (Acari: Ixodidae) and their seasonal infestation rate on Camelus dromedarius (Mammalia: Camelidae) in Masileh region, Qom province, Iran. Persian J. Acarol. 2017, 6, 31-37.

22. Jongejan, F.; Uilenberg, G. Ticks and control methods. Rev. Sci. Tech. Off. Int. Epiz. 1994, 13, 1201-1226. [CrossRef] [PubMed]

23. Jongejan, F.; Uilenberg, G. The global importance of ticks. Parasitology 2004, 129, S3-S14. [CrossRef]

24. Almazroui, M.; Islam, M.N.; Athar, H.; Jones, P.D.; Rahman, M.A. Recent climate change in the Arabian Peninsula: Annual rainfall and temperature analysis of Saudi Arabia for 1978-2009. Int. J. Climatol. 2012, 32, 953-966. [CrossRef]

25. Al-Khalifa, M.S.; Al-Asgah, N.A.; Diab, F.M. Ticks (Acari: Ixodidae) infesting common domestic animals in Al-Qasim Province, Saudi Arabia. J. Med. Entomol. 1984, 21, 114-115. [CrossRef]

26. Diab, F.M.; Hoogstraal, H.; Wassef, H.Y.; Al Khalifa, M.S.; Al Asgah, N.A. Hyalomma (Hyalommina) arabica: Nymphal and larval identity and spiny mouse hosts in Saudi Arabia (Acarina: Ixodoidea: Ixodidae). J. Parasitol. 1985, 71, 630-634. [CrossRef]

27. Bakheit, M.; Latif, A.; Vatansever, Z.; Seitzer, U.; Ahmed, J. The huge risks due to Hyalomma ticks. In Arthropods As Vectors of Emerging Diseases; Mehlhorn, H., Ed.; Springer: Berlin, Germany, 2012.

28. Saliba, E.K.; Amr, Z.S.; Wassef, H.Y.; Hoogstraal, H.; Main, A.J. The ticks (Ixodoidea) of East Jordan and the West Bank. Dirasat 1990, 17B, 156-175.

29. Anonymous. Regional Disease Vector Ecology Profile: The Middle East. Pest Manag. Inf. Anal. Center Armed Forces Pest Manag. Board For. Glen Sect. Walter Reed Army Med. Center. 1999; pp. 1-209. Available online: https://apps.dtic.mil/dtic/tr/fulltext/u2 /a605893.pdf (accessed on 15 January 2020). 
30. Gabaj, M.M.; Awan, M.A.Q.; Beesley, W.N. A survey of ticks on farm animals in Libya. Ann. Trop. Med. Parasitol. 1992, 86, 543-548. [CrossRef] [PubMed]

31. Hoogstraal, H. Ornithodoros salahi sp. nov.(Ixodoidea, Argasidae) from the Cairo Citadel, with Notes on O. piriformis Warburton, 1918 and O. batuensis Hirst, 1929. J. Parasitol. 1953, 39, 256-263. [CrossRef]

32. Chalon, G. Présence d'Ornithodoros savignyi (Audouin) à Ouargla (Sahara algérien). Bull. Soc. Pathol. Exot. 1923, 16, 741-742.

33. Pegram, R.G.; Hoogstraal, H.; Wassef, H.Y. Ticks (Acari: Ixodoidea) of the Yemen Arab Republic. I. Species infesting livestock. Bull. Entomol. Res. 1982, 72, 215-227. [CrossRef]

34. Wassef, H.Y.; Buttiker, W.; Gallagher, M.D. Further records of ticks (Acari: Argasidae and Ixodidae) from Arabian Peninsula. Fauna Saudi Arab. 1997, 16, 63-88.

35. Hoogstraal, H.; Kaiser, M.N. Observations on Ticks (Ixodoidea) of Libya. Ann. Entomol. Soc. Am. 1960, 53, 445-457. [CrossRef]

36. Sylla, P.M.; Molez, J.F.; Cornet, J.P.; Camicas, J.L. Climate change and distribution of ticks (Acari: Ixodida) in Senegal and Mauritania. Acarologia 2008, 48, 137-153.

37. Davis, G.E.; Hoogstraal, H. The Relapsing Fevers: A Survey of the Tick-borne Spirochetes of Egypt. J. Egypt. Public Health Assoc. 1954, 29, 139-143.

38. Al-Mayah, S.H.; Hatem, A.N. Species diversity, prevalences and some ecological aspects of Ectoparasites of buffalo Bubalus bubalis in Basrah Province, Iraq. J. Entomol. Zool. Stud. 2018, 6, 390-394.

39. Khan, A.S.; Maupin, G.O.; Rollin, P.E.; Noor, A.M.; Shurie, H.H.M.; Shalabi, A.G.A.; Wasef, S.; Haddad, Y.M.A.; Sadek, R.; Ijaz, K.; et al. An outbreak of Crimean- Congo hemorrhagic fever in the United Arab Emirates, 1994-1995. Am. J. Trop. Med. Hyg. 1997, 57, 519-525. [CrossRef] [PubMed]

40. Hoogstraal, H.; Kaiser, M.N. Ticks (Ixodoidea) of Arabia with special reference to Yemen. Fieldiana Zool. 1959, 39, $297-322$.

41. El Kammah, K.M.; Oyoun, L.M.; El Kady, G.A.; Shafy, S.A. Investigation of blood parasites in livestock infested with argasid and ixodid ticks in Egypt. J. Egypt. Soc. Parasitol. 2001, 31, 365-371. [PubMed]

42. Salih, D.A.; Julla, I.I.; Hassan, S.M.; Hussein, A.M.E.L.; Jongejan, F. Preliminary survey of ticks (Acari: Ixodidae) on. Onderstepoort J. Vet. Res. 2008, 53, 47-53.

43. Hassan, M.I.; Gabr, H.S.; Abdel-Shafy, S.; Hammad, K.M.; Mokhtar, M.M. Prevalence of tick-vectors of Theileria annulata infesting the one-humped camels in Giza, Egypt. J. Egypt. Soc. Parasitol. 2017, 47, 425-432.

44. Mokhtaria, K.; Ammar, A.A.; Mohammed Ammar, S.S.; Chahrazed, K.; Fadela, S.; Belkacem, B.T. Survey on species composition of Ixodidae tick infesting cattle in Tiaret (Algeria). Trop. Agric. 2018, 95, 102-105.

45. Dabaja, M.F.; Tempesta, M.; Bayan, A.; Vesco, G.; Greco, G.; Torina, A.; Blanda, V.; La Russa, F.; Scimeca, S.; Lelli, R.; et al. Diversity and distribution of ticks from domestic ruminants in Lebanon. Vet. Ital. 2017, 53, 147-155.

46. Shamsuddin, M.; Mohammad, M.K. Incidence, distribution, and host relationships of some ticks (Ixodoidea) in Iraq. J. Univ. Kuwait 1988, 15, 321-329.

47. Omer, L.T.; Kadir, M.A.A.; Seitzer, U.; Ahmed, J.S. A survey of ticks (Acari:Ixodidae) on cattle, sheep and goats in the Dohuk Governorate, Iraq. Parasitol. Res. 2007, 101, 179-181. [CrossRef] [PubMed]

48. El-Rabie, Y.; Amr, Z.S.; Hyland, K.E. Observations on the ixodid ticks associated with domestic ungulate animals in Jordan. Zool. Middle East 1990, 4, 85-92. [CrossRef]

49. Yousfi-Monod, R.; Aeschlimann, A. Studies on ticks (Acarina, Ixodidae), parasites of cattle in West Algeria. I. Systematic survey and seasonal activity. Ann. Parasitol. Hum. Comp. 1986, 61, 341-358. [CrossRef] [PubMed]

50. Bouattour, A.; Darghouth, M.A.; Daoud, A. Distribution and ecology of ticks (Acari: Ixodidae) infesting livestock in Tunisia: An overview of eighth years field collections. Parassitologia 1999, 41, 5-10. [PubMed]

51. Asmaa, N.M.; ElBably, M.A.; Shokier, K.A. Studies on prevalence, risk indicators and control options for tick infestation in ruminants. Beni-Suef Univ. J. Basic Appl. Sci. 2014, 3, 68-73. [CrossRef]

52. Hasson, R.H. Tick distribution and infestation among sheep and cattle in Baghdad 's south suburb. Kufa J. Vet. Med. Sci. 2012, 3, 77-90.

53. Djerbouh, A.; Kernif, T.; Beneldjouzi, A.; Socolovschi, C.; Kechemir, N.; Parola, P.; Raoult, D.; Bitam, I. The first molecular detection of Rickettsia aeschlimannii in the ticks of camels from southern Algeria. Ticks Tick Borne Dis. 2012, 3, 373-375. [CrossRef]

54. Abdel-Shafy, S.; Allam, N.A.T.; Mediannikov, O.; Parola, P.; Raoult, D. Molecular Detection of Spotted Fever Group Rickettsiae Associated with Ixodid Ticks in Egypt. Vector-Borne Zoonotic Dis. 2012, 12, 346-359. [CrossRef]

55. Hagras, A.E.; Khalil, G.M. Effect of Temperature on Hyalomma (Hyalomma) dromedarii Koch (Acari: Ixodidae). J. Med. Entomol. 1988, 25, 354-359. [CrossRef]

56. Leulmi, H.; Aouadi, A.; Bitam, I.; Bessas, A.; Benakhla, A.; Raoult, D.; Parola, P. Detection of Bartonella tamiae, Coxiella burnetii and rickettsiae in arthropods and tissues from wild and domestic animals in northeastern Algeria. Parasites Vectors 2016, 9, 1-8. [CrossRef] [PubMed]

57. Camicast, J.; Wilson, M.L.; Cornett, J.; Digoutte, J. Ecology of ticks as potential vectors of Crimean-Congo hemorrhagic fever virus in Senegal: Epidemiological implications. Arch. Virol. 1990, 1, 303-322.

58. Khalil, G.M.; Hagras, A.E. Effect of Temperature on Hyalomma (Hyalomma) impeltatum Schulze and Schlottke (Ixodoidea: Ixodidae). Qatar Univ. Sci. J. 1988, 8, 187-204. 
59. Bitam, I.; Parola, P.; Matsumoto, K.; Rolain, J.M.; Baziz, B.; Boubidi, S.C.; Harrat, Z.; Belkaid, M.; Raoult, D. First Molecular Detection of R. conorii, R. aeschlimannii, and R. massiliae in Ticks from Algeria. Ann. N. Y. Acad. Sci. 2006, 372, 368-372. [CrossRef] [PubMed]

60. Dib, L.; Bitam, I.; Bensouilah, M.; Parola, P.; Raoult, D.; Mokhtar, B. First description of Rickettsia monacensis in Ixodes ricinus in Algeria. Clin. Microbiol. Infect. 2009, 15, 261-262. [CrossRef]

61. Hassan, M.I.; Gabr, H.; Abdel-shafy, S.; Mokhtar, M.M. Molecular detection of Borrelia sp. In Ornithodoros savignyi and Rhipicephalus annulatus by FlaB gene and Babesia bigemina in R. annulatus by $18 \mathrm{~S}$ rRNA gene. J. Egypt. Soc. Parasitol. 2017, 47, 403-414.

62. Abdel-Shafy, S. Microbiological and Control Studies on Ticks Infesting Farm Animals and Poultry. Ph.D. Thesis, Faculty of Agriculture, Cairo University, Cairo, Egypt, 2000.

63. Abaker, I.A.; Salih, D.A.; El Haj, L.M.; Ahmed, R.E.; Osman, M.M.; Ali, A.M. Prevalence of Theileria annulata in dairy cattle in Nyala, South Darfur State, Sudan. Vet. World 2017, 10, 1475-1480. [CrossRef]

64. El-Tigani, M.A.; Mohammed, A.S. Ticks (Acari: Ixodidae) Infesting Camels in El Butana Area Mid-Central Sudan. Sudan J. Vet. Res. 2010, 25, 51-54.

65. Nabeth, P.; Cheikh, D.O.; Lo, B.; Faye, O.; Ould, I.; Vall, M. Crimean-Congo Hemorrhagic Fever, Mauritania. Emerg. Infect. Dis. 2004, 10, 2143-2149. [CrossRef]

66. Ali, M.M.A. Studies on Ticks and Tick-Borne Diseases of Cattle in South Darfur State, Sudan. Ph.D. Thesis, Department of Parasitology Faculty of Veterinary Medicine University of Khartoum, Khartoum, Sudan, 2007.

67. Diab, F.; Al-Khalifa, M.; Al-Asgah, N.; Hussein, H.; Khalil, G. Ticks (Acari: Argasidae, Ixodidae) infesting livestock in Saudi Arabia. Fauna Arab. 2006, 22, 233-243.

68. Pegram, R.G.; Zivkovic, D.; Jongejan, F. Ticks (Acari: Ixodoidea) of the Yemen Arab Republic. II. The Rhipicephalus sanguineus (Latreille) group. Bull. Ent. Res. 1989, 79, 259-263. [CrossRef]

69. Ahmed, B.M.; El Hussein, A.M.; El Khider, A.O. Some observations on ticks (Acari: Ixodidae) infesting sheep in River Nile Province of Northern Sudan. Onderstepoort J. Vet. Res. 2005, 72, 239-243. [CrossRef]

70. Arthur, D.R. Ticks in Egypt in 1500 BC? Nature 1965, 206, 1060-1061. [CrossRef]

71. Hoogstraal, H.; Traylor, M.A.; Gaber, S.; Malakatis, G.; Guindy, E.; Helmy, I. Ticks (Ixodidae) on Migrating Birds in Egypt, Spring and Fall 1962. Bull. World Health Organ. 1964, 30, 355-367. [PubMed]

72. El-Kammah, K.M.; Oyoun, L.M.I.; Abdel-Shafy, S. Tick-host relationships and keys to the immatures of six ixodid species recorded in Egypt. Bull. Zool. Soc. Egypt 1997, 44, 8-16.

73. Hoogstraal, H. African Ixodoidae: Ticks of Sudan (with Special Reference to Equatoria Province and with Preliminary Reviews of the Genera Boophilus, Margaropus, and Hyalomma); Research Report NM 005 050.29.07; Department of Medical Zoology, U.S. Naval Medical Research Unit No. 3: Cairo, Egypt, 1956; pp. 1-598.

74. Mazyad, S.A.; Khalaf, S.A. Studies on Theileria and Babesia infecting live and slaughtered animals in Al Arish and El Hasanah, North Sinai Governorate, Egypt. Egypt. J. Egypt. Soc. Parasitol. 2002, 32, 601. [PubMed]

75. Renneker, S.; Abdo, J.; Bakheit, M.A.; Kullmann, B.; Beyer, D.; Ahmed, J.; Seitzer, U. Coinfection of Sheep with Anaplasma, Theileria and Babesia Species in the Kurdistan Region, Iraq. Transbound. Emerg. Dis. 2013, 60, 113-118. [CrossRef]

76. FAOSTAT. FAO Statistics Division. 2018. Available online: http//www.fao.org/faostat/en/\#data (accessed on 21 September 2020).

77. Hoogstraal, H.; Kaiser, M.N. The Ticks (Ixodoidea) of Iraq: Keys, Hosts, and Distribution. Distrib. J. Iraqi Med. Prof. 1958, 6, 22.

78. Robson, J.; Robb, J.M.; Hawa, N.J. Ticks (Ixodoidea) of Domestic Animals in Iraq Part 3: Autumn infestations in the Liwas of Kut, Amara and Basra; winter and summer infestations in the Liwa of Baghdad. J. Med. Entomol. 1968, 5, 257-261. [CrossRef]

79. Mohammad, M.K. Ixodiod Tick Fauna Infesting Sheep and Goats in the Middle and South of Iraq. Bull. Iraq Nat. Hist. Mus. 2016, $14,43-50$.

80. Mohammad, M.K. A Bio-Taxonomic Study on the Hard Ticks (Acari Ixodidae) of some Domestic and Wild Animal from Iraq. Ph.D. Thesis, College of Sciences, University of Baghdad, Baghdad, Iraq, 1996.

81. Mohammad, M.K. Distribution of Ixodid Ticks Among Domestic and Wild Animals in Central Iraq. Bull. Iraq Nat. Hist. Mus. 2015, 13, 23-30.

82. Awad, A.H.H.; Abdul-Hussein, M.A. Epidemiological Study on the Hard Ticks of Some Domestic Animals in Basrah. Basrah J. Sci. 2005, 23, 93-108.

83. Awad, A.H.H.; Hussein, M.A.A. New Record of Two Species of Hard Ticks from Some Domestic Animals in Basrah. J.Basrah Res. 2006, 32, 1-6.

84. Tuama, S.J.; Al-Zihiry, K.J.K.; Al-Maliky, H.K. Ticks infesting some domestic animals in Thi-Qar Province, Southern Iraq. J. Missan Res. 2007, 4, 1-12.

85. Muhaidi, M.J.; Alkubaisy, A.B.H.; Ahmed, M.N.; Hamed, M.A. Study of Prevalence of Ticks genus Hyalomma spp. and Boophilus spp. of mammalian In Villages Al-Fallouja City. Al-Anbar J. Vet. Sci. 2010, 3, 30-36.

86. Mohammad, M.K.; Jassim, S.Y. Distribution of Hard Tick Species among Sheep Ovis aries L. in Al-Anbar Province, Western Desert of Iraq. Bull. Iraq Nat. Hist. Mus. 2011, 11, 27-31.

87. Zangana, I.K.; Ali, B.A.; Naqid, I.A. Distribution of Ectoparasites Infested Sheep and Goats in Duhok Province, North Iraq. Bas. J. Vet. Res. 2013, 12, 54-64. 
88. Mallah, M.O.; Rahif, R.H. Epidemiological study for ticks infestation in cattle in Baghdad city-Iraq. Al-Qadisiyah J. Vet. Med. Sci. 2016, 15, 45-51.

89. Robson, J.; Robb, J.M.; Hawa, N.J. Ticks (Ixodoidea) of Domestic Animals in Iraq Part 5: Infestations in the Liwas of Diwaniya and Nasiriya (spring), Karbala (winter), and Hilla (autumn and winter). J. Med. Entomol. 1969, 6, 120-124. [CrossRef]

90. Robson, J.; Robb, J.M.; Hawa, N.J.; Al-Wahayyib, T. Ticks (Ixodoidea) of Domestic Animals in Iraq: Part 6. Distribution. J. Med. Entomol. 1969, 6, 125-127. [CrossRef]

91. Robson, J.; Robb, J.M.; Hawa, N.J. Ticks (Ixodoidea) of Domestic Animals in Iraq Part 4: A comparison of infestations in winter and early summer in the Liwa of Mosul. J. Med. Entomol. 1968, 5, 261-264. [CrossRef] [PubMed]

92. Robson, J.; Robb, J.M.; Al-Wahayyib, T. Ticks (Ixodoidea) of Domestic Animals in Iraq Part 2: Summer infestations in the Liwas of Hilla, Karbala, Diwaniya and Nasiriya. J. Med. Entomol. 1968, 5, 27-31. [CrossRef] [PubMed]

93. Robson, J.; Robb, J.M.; Hawa, N.J.; Al-Wahayyib, T. Ticks (Ixodoidea) of Domestic Animals in Iraq: Part 7. Seasonal incidence on cattle, sheep and goats in the Tigris-Euphrates valley plain. J. Med. Entomol. 1969, 6, 127-130. [CrossRef]

94. Robson, J.; Robb, J.M. Ticks (Ixodoidea) of Domestic Animals in Iraq Spring and early summer infestations in the Liwas of Baghdad, Kut, Amara, and Basra. J. Med. Entomol. 1967, 4, 289-293. [CrossRef]

95. Ali, A.A.N.; Al-Emarah, G.Y.; Al-Amura, M.F.A.; Suzan, A.A.A.-A.; Afrah, A.H. Detection of Ectoparasites between Domesticated Animals in Basrah City/Southern Iraq. J. Int. Acad. Res. Multidiscip. 2014, 2, 221-235.

96. Hasson, R.H.; Al-zubaidi, H.H. Sheep and goats tick' s infestation in Wasit's districts. Iraqi J. Vet. Med. 2012, 36, $299-305$.

97. Kadir, M.A.; Zangana, I.K.; Mustafa, B.H.S. A study on epidemiology of hard tick (Ixodidae) in sheep in Sulaimani governorateIraq. Iraqi J. Vet. Sci. 2012, 26, 95-103.

98. Babudieri, B. Relapsing fever in Jordan. Bull. World Health Organ. 1957, 16, 911-928.

99. Sherkov, S.U.; El-Rabei, Y.; Kakash, L. A survey of parasitic blood diseases; “Tick-Borne Fever” in domestic animals in Jordan. Egypt. J. Vet. Sci. 1977, 13, 29-35.

100. Hoogstraal, H.; Wassef, H.Y.; Buttiker, W. Ticks (Acarina) of Saudi Arabia. Fam. Argasidae, Ixodidae. Fauna Saudi Arab. 1981, 3 , 25-110.

101. Rahbari, S.; Nabian, S.; Shayan, P. Primary report on distribution of tick fauna in Iran. Parasitol. Res. 2007, 101, 175-177. [CrossRef] [PubMed]

102. Yeruham, I.; Hadani, A.; Galker, E.; Rosen, S. The seasonal occurrence of ticks (Acari: Ixodidae) on sheep and in the field in the Judean area of Israel. Exp. Appl. Acarol. 1996, 20, 47-56. [PubMed]

103. Converse, J.D.; Moussa, M.I. Virus From Hyalomma dromedarii (Acari: Ixodoidea) collected in Kuwait, Iraq and Yemen. J. Med. Entomol. 1982, 19, 209-210. [CrossRef] [PubMed]

104. Apanaskevich, D.A.; Horak, I.G. The genus Hyalomma Koch, 1844. I. Reinstatement of Hyalomma (Euhyalomma) glabrum Delpy, 1949 (Acari, Ixodidae) as a valid species with a redescription of the adults, the first description of. Onderstepoort J. Vet. Res. 2006, 73, 1-12. [CrossRef] [PubMed]

105. Hoogstraal, H.; Tatchell, R.J. Ticks parasitizing livestock. In Ticks and Tick-Borne Diseases Control. A Practical Field Manual. Tick Control; FAO: Rome, Italy, 1985; Volume 1, pp. 1-73.

106. Otranto, D.; Huchet, J.; Giannelli, A.; Callou, C.; Dantas-torres, F. The enigma of the dog mummy from Ancient Egypt and the origin of 'Rhipicephalus sanguineus'. Parasit. Vectors 2014, 7, 2-6. [CrossRef]

107. Fernández de Mera, I.G.; Blanda, V.; Torina, A.; Dabaja, M.F.; El Romeh, A.; Cabezas-cruz, A.; de la Fuente, J. Identification and molecular characterization of spotted fever group rickettsiae in ticks collected from farm ruminants in Lebanon. Ticks Tick Borne Dis. 2018, 9, 104-108.

108. Raad, M.; Azar, D.; Perotti, M.A. First Report of the Ticks Haemaphysalis punctata Canestrini et Fanzago, 1878, Haemaphysalis parva (Neumann, 1897) and Dermacentor marginatus (Sulzer, 1776) (Acari, Amblyommidae) from Humans in Lebanon. Acta Parasitol. 2020, 65, 541-545. [CrossRef]

109. Onorato, R. Le miasi in Tripolitania. Arch. Ital. Sci. Med. Colon. 1922, 3, 14-315.

110. Franchini, G.; Taddia, L. Febbre da punctura di zecche in Cyrenaica causata dalla Ornithodorus franchinii (n. sp.). Arch. Ital. Sci. Med. Colon. 1930, 11, 453-458.

111. Coghill, N.F.; Lawrence, J.; Ballantine, I.D. Relapsing fever in cyrenaica. Br. Med. J. 1947, 1, 637-640. [CrossRef]

112. Giordano, M.; Nastasi, A. La febbre esantematica del littorale Mediterraneo in Tripolitania. Arch. Ital. Sci. Med. Colon. 1935, 16, 101-185.

113. Beesley, W.N.; Gabaj, M.M. New records for Rhipicephalus bursa, Boophilus microplus, B.decoloratus and Hypoderma lineatum from Libya. Med. Vet. Entomol. 1991, 5, 259-260. [CrossRef] [PubMed]

114. Neumann, L.G. Revision de la famille des ixodides (Memoire 4). Mem. Soc. Zool. Fr. 1901, 14, $249-372$.

115. Donitz, W. Die Zeeken des Rindes als Krankheitsiibertrager. Sitz. Der Ges. Nat. Freunde Zu Berlin 1905, 4, 105-134.

116. Scrimgeour, E.M.; Mehta, F.R.; Suleiman, A.J.M. Infectious and tropical diseases in Oman: A review. Am. J. Trop. Med. Hyg. 1999, 61, 920-925. [CrossRef] [PubMed]

117. Hoogstraal, H. Ticks (Ixodoidea) from Oman. J. Oman Stud. 1980, 2, 265-272.

118. Papadopoulos, B.; Büttiker, W.; Morel, P.C.; Aeschlimann, A. Ticks (Acarina, Fam. Argasidae \& Ixodidae) of Oman. Fauna Saudi Arab. 1991, 12, 200-208. 
119. Idris, M.A.; Ruppel, A.; Petney, T. Antibodies against rickettsia in humans and potential vector ticks from Dhofar, Oman. Sultan Qaboos Univ. Med. J. 2000, 2, 7-10.

120. Alanazi, A.D.; Nguyen, V.L.; Alyousif, M.S.; Manoj, R.R.; Alouffi, A.S.; Donato, R.; Sazmand, A.; Mendoza-Roldan, J.A.; DantasTorres, F. and Otranto, D. Ticks and associated pathogens in camels (Camelus dromedarius) from Riyadh Province, Saudi Arabia. Parasites Vectors 2020, 13, 1-9. [CrossRef]

121. Hussein, H.S.; Al-Asgah, N.A.; Al-Khalifa, M.S.; Diab, F.M. The blood parasites of indigenous livestock in Saudi Arabia. Arab Gulf J. Sci. Res. 1991, 9, 143-160.

122. Al-Khalifa, M.S.; Hussein, H.S.; Diab, F.M.; Khalil, G.M. Blood parasites of livestock in certain Regions in Saudi Arabia. Saudi J. Biol. Sci. 2009, 16, 63-67. [CrossRef] [PubMed]

123. Al-Asgah, N.A.; Hussein, H.S.; Al-Khalifa, M.S.; Diab, F.M. Hyalomma schulzei (the large camel tick): Distribution in Saudi Arabia. J. Med. Entomol. 1985, 22, 230-231. [CrossRef] [PubMed]

124. Alanazi, A.D.; Al-Mohammed, H.I.; Alyousif, M.S.; Said, A.E.; Salim, B.; Abdel-Shafy, S.; Shaapan, R.M. Species diversity and seasonal distribution of hard ticks (Acari: Ixodidae) infesting mammalian hosts in various districts of Riyadh Province, Saudi Arabia. J. Med. Entomol. 2019, 56, 1027-1032. [CrossRef] [PubMed]

125. Al-Shammery, K.A.; Fetoh, B.E.A.; Alshammari, A.M. Differentiation between Common Tick Species Using Molecular Biology Techniques in Saudi Arabia. Int. J. Biotechnol. Bioeng. 2011, 5, 9-11.

126. Hoogstraal, H. A Preliminary, Annotated List of Ticks (Ixodoidea) of the Anglo-Egyptian Sudan. Am. Soc. Parasitol. 1954, 40, 304-310. [CrossRef]

127. Karrar, G.; Kaiser, M.N.; Hoogstraal, H. Ecology and host-relationships of ticks (Ixodoidea) infesting domestic animals in Kassala Province, Sudan, with special reference to Amblyomma lepidum Dönitz. Bull. Entomol. Res. 1963, 54, 509-522. [CrossRef]

128. Jongejan, F.; Zivkovic, D.; Pegram, R.G.; Tatchell, R.J.; Fison, T. Ticks(Acari:Ixodidae) of the Blue and White Nile Ecosystems in the Sudan with Particular Reference to the Rhipicephalus sanguineus Group. Exp. Appl. Aearol. 1987, 3, 331-346. [CrossRef]

129. El-Hussein, A.R.M.; Majid, A.M.A.; Shawgi, M.H. Present status of tick-borne diseases in Sudan. Arch. Inst. Pasteur. Tunis 2004, $81,1-4$.

130. Osman, A.M. Ticks infesting sheep and goats in the Sudan. Parassitologia 1997, 39, 139-142.

131. ElGhali, A.; Hassan, S.M. Ticks infesting animals in the Sudan and southern Sudan: Past and current status. J. Vet. Res. 2012, 79, 1-6. [CrossRef]

132. Mustafa, H.; Jongejan, F.; Morzaria, S.P. Note on the transmission of Theileria annulata by Hyalomma ticks in the Sudan. Vet. Q. 1983, 5, 3-6. [CrossRef] [PubMed]

133. Rjeibi, M.R.; Darghouth, M.A.; Rekik, M.; Amor, B.; Sassi, L.; Gharbi, M. First Molecular Identification and Genetic Characterization of Theileria lestoquardi in Sheep of the Maghreb Region. Transbound. Emerg. Dis. 2016, 63, 278-284. [CrossRef] [PubMed]

134. Alaa, M.; Alhasan, H.; Xuan, N.; Sabagh, A.; Awier, K.; Cao, S.; Goo, Y.; Aboge, G.; Yokoyama, N.; Nishikawa, Y.; et al. Molecular and serological prevalence of Babesia bovis and Babesia bigemina in cattle from central region of Syria. Vet. Parasitol. 2012, 187, 307-311.

135. Bouattour, A.; Darghouth, M.A.; Ben Miled, L. Cattle infestation by Hyalomma ticks and prevalence of Theileria in H. detritum species in Tunisia. Vet. Parasitol. 1996, 65, 233-245. [CrossRef]

136. Ros-García, A.; M'Ghirbi, Y.; Bouattour, A.; Hurtado, A. First detection of Babesia occultans in Hyalomma ticks from Tunisia. Parasitology 2011, 138, 578-582. [CrossRef]

137. Younsi, H.; Postic, D.; Baranton, G.; Bouattour, A. High prevalence of Borrelia lusitaniae in Ixodes ricinus ticks in Tunisia. Eur. J. Epidemiol. 2001, 17, 53-56. [CrossRef]

138. Sarih, M.H.; Ghirbi, Y.M.; Bouattour, A.; Gern, L.; Baranton, G. Detection and Identification of Ehrlichia spp. in Ticks Collected in Tunisia and Morocco. J. Clin. Microbiol. 2005, 43, 1127-1132. [CrossRef]

139. M'ghirbi, Y.; Hurtado, A.; Bouattour, A. Theileria and Babesia Parasites in Ticks in Tunisia. Transbound. Emerg. Dis. 2010, 1, 49-51. [CrossRef]

140. Demoncheaux, J.P.; Socolovschi, C.; Davoust, B.; Haddad, S.; Raoult, D.; Parola, P. First detection of Rickettsia aeschlimannii in Hyalomma dromedarii ticks from Tunisia. Ticks Tick Borne Dis. 2012, 3, 398-402. [CrossRef]

141. M'ghirbi, Y.; Hurtado, A.; Brandika, J.; Khlif, K.; Ketata, Z.; Bouattour, A. A molecular survey of Theileria and Babesia parasites in cattle, with a note on the distribution of ticks in Tunisia. Parasitol. Res. 2008, 103, 435. [CrossRef]

142. Perveen, N.; Bin Muzaffar, S.; Al-Deeb, M.A. Population dynamics of Hyalomma dromedarii on camels in the United Arab Emirates. Insects 2020, 11, 320. [CrossRef] [PubMed]

143. Al-Deeb, M.A.; Muzaffar, S.B.; Abu-Zeid, Y.A.; Enan, M.R.; Karim, S. First record of a spotted fever group Rickettsia sp. and Theileria annulata in Hyalomma dromedarii (Acari: Ixodidae) ticks in the United Arab Emirates. Florida Entomol. 2015, 98, 135-139. [CrossRef]

144. Al-Deeb, M.A.; Muzaffar, S. Bin Prevalence, distribution on host's body, and chemical control of camel ticks Hyalomma dromedarii in the United Arab Emirates. Vet. World 2020, 13, 114-120. [CrossRef]

145. CVRL. 33rd Annual Report; Central Veterinary Research Laboratory: Dubai, UAE, 2019. 
146. McCartan, B.M.; Hunter, A.G.; Pegram, R.G.; Bourne, A.S. Tick infestations on livestock in the Yemen Arab Republic and their potential as vectors of livestock diseases. Tropical animal health and production. Trop. Anim. Health Prod. 1987, 19, 21-31. [CrossRef]

147. Al-Shaibani, I. Preliminary Study on Hard Ticks (Acari: Ixodidae) of Sheep in Some Areas of Thamar Governorate, Yemen. Thamar Univ. J. Nat. Appl. Sci. 2012, A, 21-31.

148. Harrus, S.; Baneth, G. Drivers for the emergence and re-emergence of vector-borne protozoal and bacterial diseases. Int. J. Parasitol. 2005, 35, 1309-1318. [CrossRef] [PubMed]

149. Collinge, S.K.; Ray, C. Disease Ecology: Community Strusture and Pathogen Dynamics; Oxford University Press: Oxford, UK, 2006; ISBN 9780198567073.

150. Gayle, A.; Ringdahl, E. Tick-borne Diseases. Am. Fam. Physician 2001, 64, 461-466. [PubMed]

151. Bowman, A.S.; Nuttall, P.A. Parasitology; Cambridge University Press: Cambridge, UK, 2008.

152. Nicholson, W.L.; Sonenshine, D.E.; Lane, R.S.; Uilenberg, G. Ticks (Ixodoidea). In Medical and Veterinary Entomology, 2nd ed.; Mullen, G.R., Durden, L.A., Eds.; Elsevier, Inc.: Amsterdam, The Netherlands, 2009; pp. 493-542.

153. Bratton, R.L.; Corey, G.R. Tick-Borne Diseases. Emerg. Med. 2005, 71, 2323-2330.

154. De la Fuente, J.; Estrada-Pena, A.; Venzal, J.M.; Kocan, K.M.; Sonenshine, D.E. Overview: Ticks as vectors of pathogens that cause disease in humans and animals. Front. Biosci. 2008, 13, 6938-69468. [CrossRef]

155. Suksawat, J.; Xuejie, Y.; Hancock, S.I.; Hegarty, B.C.; Nilkumhang, P.; Breitschwerdt, E.B. Serologic and Molecular Evidence of Coinfection with Multiple Vector-Borne Pathogens in Dogs from Thailand. J. Vet. Intern. Med. 2001, 15, 453-462. [CrossRef]

156. Kordick, S.K.; Breitschwerdt, E.B.; Hegarty, B.C.; Southwick, K.L.; Colitz, C.M.; Hancock, S.I.; Bradley, J.M.; Rumbough, R.; Pherson, J.T.M.C. Coinfection with Multiple Tick-Borne Pathogens in a Walker Hound Kennel in North Carolina. J. Clin. Microbiol. 1999, 37, 2631-2638. [CrossRef] [PubMed]

157. Suksawat, J.; Pitulle, C.; Arraga-alvarado, C.; Madrigal, K.; Hancock, S.I.; Breitschwerdt, E.B. Coinfection with Three Ehrlichia Species in Dogs from Thailand and Venezuela with Emphasis on Consideration of 16S Ribosomal DNA Secondary Structure. J. Clin. Microbiol. 2001, 39, 90-93. [CrossRef] [PubMed]

158. Pfäffle, M.; Littwin, N.; Muders, S.V.; Petney, T.N. The ecology of tick-borne diseases. Int. J. Parasitol. 2013, 43, 1059-1077. [CrossRef] [PubMed]

159. Rajput, Z.I.; Hu, S.H.; Chen, W.J.; Arijo, A.G.; Xiao, C.W. Importance of ticks and their chemical and immunological control in livestock. J. Zhejiang Univ. Sci. B 2006, 7, 912-921. [CrossRef]

160. Dantas-Torres, F.; Chomel, B.B.; Otranto, D. Ticks and tick-borne diseases: A One Health perspective. Trends Parasitol. 2012, 28, 437-446. [CrossRef]

161. A'aiz, N.N.; Dhaim, Y.A. Prevalence of Theileriosis in sheep in Al-Kut province in Iraq. Int. J. Adv. Res. $2014,2,514-519$.

162. Alkishe, A.A.; Peterson, A.T.; Samy, A.M. Climate change influences on the potential geographic distribution of the disease vector tick Ixodes ricinus. PLoS ONE 2017, 12, 1-14. [CrossRef]

163. Darwish, M.A.; Imam, I.Z.E.; Omar, F.M.; Hoogstraal, H. Results of a preliminary seroepidemiological survey for Crimean-Congo hemorrhagic fever virus in Egypt. Acta Virol. 1978, 22, 77.

164. Hoogstraal, H. The Epidemiology of Tick-borne Crimean-Congo Hemorrhagic Fever in Asia, Europe and Africa. J. Med. Entomol. 1979, 15, 307-417. [CrossRef]

165. Suleiman, M.N.E.H.; Muscat-Baron, J.M.; Harries, J.R.; Satti, A.G.O.; Platt, G.S.; Bowen, E.T.W.; Simpson, D.I.H. Congo/Crimean haemorrhagic fever in Dubai: An outbreak at the Rashid Hospital. Lancet 1980, 316, 939-941. [CrossRef]

166. Al-Tikriti, S.K.; Al-Ani, F.; Jurji, F.J.; Tantawi, H.; Mahmud, M.I.A.; Habib, H.; Al-janabi, S.H.; Yonan, M.; Hassan, F.; Simpson, D.I.H. Congo/Crimean haemorrhagic fever in Iraq. Bull. World Health Organ. 1981, 59, 85-90. [PubMed]

167. Baskerville, A.; Satti, A.G.O.; Murphy, F.A.; Simpson, D.I.H. Congo-Crimean haemorrhagic fever in Dubai: Histopathological studies. J. Clin. Pathol. 1981, 34, 871-874. [CrossRef] [PubMed]

168. Al-Nakib, W.; Lloyd, G.; El-Mekki, A.; Platt, G.; Beeson, A.; Southee, T. Preliminary report on arbovirus-antibody prevalence among patients in Kuwait: Evidence of Congo/Crimean virus infection. Trans. R. Soc. Trop. Med. Hyg. 1984, 78, 474-476. [CrossRef]

169. Saluzzo, J.F.; Aubry, P.; Digoutte, J.P. Haemorrhagic fever caused by Crimean Congo Haemorrhagic Fever virus in Mauritania. Trans. R. Soc. Trop. Med. Hyg. 1985, 79, 268. [CrossRef]

170. Gonzalez, J.P.; LeGuenno, B.; Guillaud, M.; Wilson, M.L. A fatal case of Crimean-Congo haemorrhagic fever in Mauritania: Virological and serological evidence suggesting epidemic transmission. Trans. R. Soc. Trop. Med. Hyg. 1990, 84, 573-576. [CrossRef]

171. Morrill, J.C.; Soliman, A.K.; Imam, I.Z.; Botros, B.A.M.; Moussa, M.I.; Watts, D.M. Serological evidence of Crimean-Congo haemorrhagic fever viral infection among camels imported into Egypt. J. Trop. Med. Hyg. 1990, 93, $201-204$.

172. Scrimgeourl, E.M.; Zaki, A.; Mehta, F.R.; Abraham, A.K.; Al-Busaidy, S.; El-Khatim, H.; Mohammed, A.J. Crimean-Congo in Oman haemorrhagic fever in Oman. Trans. R. Soc. Trop. Med. Hyg. 1996, 90, 290-291. [CrossRef]

173. Schwarz, T.E.; Nsanze, H.; Ameen, A.M. Clinical Features of Crimean-Congo Haemorrhagic Fever in the United Arab Emirates. Infection 1997, 25, 40-43. [CrossRef] 
174. Rodriguez, L.L.; Maupin, G.O.; Ksiazek, T.G.; Rollin, P.E.; Khan, A.L.S.; Schwarz, T.E.F.; Lofts, R.S.; Smith, J.F.; Noor, A.M.; Peters, C.J.; et al. Molecular investigation of a multisource outbreak of Crimean-Congo hemorrhagic fever in the United Arab Emirates. Am. J. Trop. Med. Hyg. 1997, 57, 512-518. [CrossRef]

175. Hassanein, K.M.; El-Azazy, O.M.E.; Yousef, H.M. Detection of Crimean-Congo haemorrhagic fever virus antibodies in humans and imported livestock in Saudi Arabia. Trans. R. Soc. Trop. Med. Hyg. 1997, 91, 536-537. [CrossRef]

176. Williams, R.J.; Al-Busaidy, S.; Mehta, F.R.; Maupin, G.O.; Wagoner, K.D.; Al-Awaidy, S.; Suleiman, A.J.M.; Khan, A.S.; Peters, C.J.; Ksiazek, T.G. Crimean-Congo haemorrhagic fever: A seroepidemiological and tick survey in the Sultanate of Oman. Trop. Med. Int. Health 2000, 5, 99-106. [CrossRef] [PubMed]

177. Elata, A.T.; Karsany, M.S.; Elageb, R.M.; Hussain, M.A.; Eltom, K.H.; Elbashir, M.I.; Aradaib, I.E. A nosocomial transmission of crimean-congo hemorrhagic fever to an attending physician in north kordufan, Sudan. Virol. J. 2011, 8, 1-7. [CrossRef] [PubMed]

178. Aradaib, I.E.; Erickson, B.R.; Karsany, M.S.; Khristova, M.L.; Elageb, R.M.; Mohamed, M.E.H.; Nichol, S.T. Multiple CrimeanCongo hemorrhagic fever virus strains are associated with disease outbreaks in Sudan, 2008-2009. PLoS Negl. Trop. Dis. 2011, 5, 2008-2009. [CrossRef] [PubMed]

179. Abul-Eis, E.S.; Mohammad, N.A.; Wasein, S.M. Crimean-Congo Hemorrhagic Fever in Iraq during 2010. Iraqi. J. Vet. Med. 2012, 36, 99-103.

180. Al-Zadjali, M.; Al-hashim, H.; Al-gh, M.; Balkha, A. A Case of Crimean-Congo Hemorrhagic Fever in Oman. Oman Med. J. 2013, 28, 210-212. [CrossRef]

181. Osman, H.A.M.; Eltom, K.H.; Musa, N.O.; Bilal, N.M.; Elbashir, M.I.; Aradaib, I.E. Development and evaluation of loop-mediated isothermal amplification assay for detection of Crimean Congo hemorrhagic fever virus in Sudan. J. Virol. Methods 2013, 190, 4-10. [CrossRef]

182. Cecaro, M.; Isolani, L.; Cuteri, V. European Monitoring Plans for the management of Outbreak of Crimean Congo Haemorrhagic Fever (CCHF). Occup. Med. Health Aff. 2013, 1, 123. [CrossRef]

183. Horton, K.C.; Wasfy, M.; Samaha, H.; Abdel-Rahman, B.; Safwat, S.; Abdel Fadeel, M.; Mohareb, E.; Dueger, E. Serosurvey for Zoonotic Viral and Bacterial Pathogens Among Slaughtered Livestock in Egypt. Vector-Borne Zoonotic Dis. 2014, 14, 633-639. [CrossRef]

184. Ibrahim, A.M.; Adam, I.A.; Osman, B.T.; Aradaib, I.E. Epidemiological survey of Crimean Congo hemorrhagic fever virus in cattle in East Darfur State, Sudan. Ticks Tick Borne Dis. 2015, 6, 439-444. [CrossRef]

185. Body, M.H.H.; ALrawahi, A.H.; Hussain, H.M.; Ahmed, M.S.; ALHabsi, S.S.; Al-Maklady, S.; Al-Maewaly, M.; Rajamony, S. Cross-sectional survey of Crimean-Congo hemorrhagic fever virus in the Sultanate of Oman. J. Vet. Med. Anim. Health 2016, 8 , 44-49.

186. Al-Dabal, L.M.; Reza, M.; Shahmirzadi, R.; Baderldin, S.; Abro, A.; Dessi, Z.; Al Eassa, E.; Khan, G.; Shuri, H.; Alwan, A.M. Crimean-Congo Hemorrhagic Fever in Dubai, United Arab Emirates, 2010: Case Report. Iran Red Crescent Med. J. 2016, 18. [CrossRef]

187. Kleib, A.S.; Salihy, S.M.; Ghaber, S.M.; Sidiel, B.W.; Sidiya, K.C.; Bettar, E.S. Crimean-Congo hemorrhagic fever with acute subdural hematoma, Mauritania, 2012. Emerg. Infect. Dis. 2016, 22, 1305-1306. [CrossRef] [PubMed]

188. Wasfi, F.; Dowall, S.; Ghabbari, T.; Bosworth, A.; Chakroun, M.; Varghese, A.; Tiouiri, H.; Ben Jemaa, M.; Znazen, A.; Hewson, R.; et al. Sero-epidemiological survey of Crimean-Congo hemorrhagic fever virus in Tunisia. Parasite 2016, 23. [CrossRef] [PubMed]

189. Kautman, M.; Tiar, G.; Papa, A.; Široký, P. AP92-like Crimean-Congo Hemorrhagic Fever Virus in Hyalomma aegyptium Ticks, Algeria. Emerg. Infect. Dis. 2016, 22, 354-356. [CrossRef] [PubMed]

190. Sas, M.A.; Mertens, M.; Isselmou, E.; Reimer, N.; El Mamy, B.O.; Doumbia, B.; Groschup, M.H. Crimean-Congo Hemorrhagic Fever Virus-Specific Antibody Detection in Cattle in Mauritania. Vector-Borne Zoonotic Dis. 2017, 17, 582-587. [CrossRef]

191. Suliman, H.M.; Adam, I.A.; Saeed, S.I.; Abdelaziz, S.A.; Haroun, E.M.; Aradaib, I.E. Crimean Congo hemorrhagic fever among the one-humped camel (Camelus dromedaries) in Central Sudan. Virol. J. 2017, 14, 1-7. [CrossRef]

192. Helmy, Y.A.; El-Adawy, H.; Abdelwhab, E.M. A comprehensive review of common bacterial, parasitic and viral zoonoses at the human-animal interface in Egypt. Pathogens 2017, 6, 33. [CrossRef]

193. Al-Abri, S.S.; Al Abaidani, I.; Fazlalipour, M.; Mostafavi, E.; Leblebicioglu, H.; Pshenichnaya, N.; Memish, Z.A.; Hewson, R.; Petersen, E.; Mala, P.; et al. Current status of Crimean-Congo haemorrhagic fever in the World Health Organization Eastern Mediterranean Region: Issues, challenges, and future directions. Int. J. Infect. Dis. 2017, 58, 82-89. [CrossRef]

194. Al-Abri, S.S.; Hewson, R.; Al-Kindi, H.; Al-Abaidani, I.; Al-Jardani, A.; Al-Maani, A.; Almahrouqi, S.; Atkinson, B.; Al-Wahaibi, A.; Al-Rawahi, B.; et al. Clinical and molecular epidemiology of Crimean-Congo hemorrhagic fever in Oman. PLoS Negl. Trop. Dis. 2019, 13, 1-15. [CrossRef]

195. Schulz, A.; Barry, Y.; Stoek, F.; Pickin, M.J.; Ba, A.; Chitimia-Dobler, L.; Haki, M.L.; Doumbia, B.A.; Eisenbarth, A.; Diambar, A.; et al. Detection of Crimean-Congo hemorrhagic fever virus (CCHFV) in Hyalomma ticks collected from Mauritanian livestock. Res. Sq. Priprint 2020, 1-20. [CrossRef]

196. Camp, J.V.; Kannan, D.O.; Osman, B.M.; Shah, M.S.; Howarth, B.; Khafaga, T.; Weidinger, P.; Karuvantevida, N.; Kolodziejek, J.; Mazrooei, H.; et al. Crimean-Congo Hemorrhagic Fever Virus Endemicity in United Arab Emirates, 2019. Emerg. Infect. Dis. 2020, 26, 2019-2021. [CrossRef] [PubMed] 
197. Charrel, R.N.; Zaki, A.M.; Fakeeh, M.; Yousef, A.I.; De Chesse, R.; Attoui, H.; Lamballerie, X. De Low Diversity of Alkhurma Hemorrhagic Fever Virus, Saudi Arabia, 1994-1999. Emerg. Infect. Dis. 2005, 11, 683-688. [CrossRef]

198. Madani, T.A. Alkhumra virus infection, a new viral hemorrhagic fever in Saudi Arabia. J. Infect. 2005, 51, 91-97. [CrossRef]

199. Charrel, R.N.; Zaki, A.M.; Fagbo, S.; de Lamballerie, X. Alkhurma hemorrhagic fever virus is an emerging tick-borne flavivirus. J. Infect. 2006, 52, 463-464. [CrossRef] [PubMed]

200. Charrel, R.N.; Fagbo, S.; Moureau, G. Alkhurma Hemorrhagic Fever Virus in Ornithodoros savignyi Ticks. Emerg. Infect. Dis. 2007, 13, 153-155. [CrossRef] [PubMed]

201. Memish, Z.A.; Charrel, R.N.; Zaki, A.M.; Fagbo, S.F. Alkhurma haemorrhagic fever-A viral haemorrhagic disease unique to the Arabian Peninsula. Int. J. Antimicrob. Agents 2010, 36, S53-S57. [CrossRef]

202. Carletti, F.; Castilletti, C.; Di Caro, A.; Capobianchi, M.R.; Nisii, C.; Suter, F.; Rizzi, M.; Tebaldi, A.; Goglio, A.; Tosi, C.P.; et al. Alkhurma Hemorrhagic Fever in Travelers Returning from Egypt, 2010. Emerg. Infect. Dis. 2010, 16, 10-13. [CrossRef]

203. Alzahrani, A.G.; Al Shaiban, H.M.; Al Mazroa, M.A.; Al-hayani, O.; Macneil, A.; Rollin, P.E.; Memish, Z.A. Alkhurma Hemorrhagic Fever in Humans, Najran, Saudi Arabia. Emerg. Infect. Dis. 2010, 16, 1882-1888. [CrossRef]

204. Memish, Z.A.; Albarrak, A.; Almazroa, M.A.; Al-omar, I.; Alhakeem, R.; Assiri, A.; Fagbo, S.; Macneil, A.; Rollin, P.E.; Abdullah, N. Seroprevalence of Alkhurma and Other Hemorrhagic Saudi Arabia. Emerg. Infect. Dis. 2011, 17, 2316-2318. [CrossRef]

205. Niang, M.; Parola, P.; Tissot-Dupont, H.; Baidi, L.; Brouqui, P.; Raoult, D. Prevalence of antibodies to Rickettsia conorii, Rickettsia africae, Rickettsia typhi and Coxiella burnetii in Mauritania. Eur. J. Epidemiol. 1998, 14, 817-818. [CrossRef]

206. Yssouf, A.; Socolovschi, C.; Kernif, T.; Temmam, S.; Lagadec, E.; Tortosa, P.; Parola, P. First molecular detection of Rickettsia africae in ticks from the Union of the Comoros. Parasites Vectors 2014, 7, 1-6. [CrossRef] [PubMed]

207. El-Maghrbi, A.; El-Sayed, I.H.; Hassaneen, A.S.; Ezeldin, N. Incidence of Theileriosis, Babesiosis and Anaplasmosis in cattle in Tripoli-Libya. Vet. Med. J. Giza 2008, 56, 71-82.

208. Awad, H.; Antunes, S.; Galindo, R.C.; do Rosário, V.E.; de la Fuente, J.; Domingos, A.; El Hussein, A.M. Prevalence and genetic diversity of Babesia and Anaplasma species in cattle in Sudan. Vet. Parasitol. 2011, 181, 146-152. [CrossRef] [PubMed]

209. Ameen, K.A.H.; Abdullah, B.A.; Abdul-Razaq, R.A. Seroprevalence of Babesia bigemina and Anaplasma marginale in domestic animals in Erbil, Iraq. Iraqi J. Vet. Sci. 2012, 26, 109-114.

210. Belkahia, H.; Ben, M.; Alberti, A.; Abdi, K.; Issaoui, Z.; Hattab, D.; Gharbi, M.; Messadi, L. First molecular survey and novel genetic variants' identification of Anaplasma marginale, A. centrale and A. bovis in cattle from Tunisia. Infect. Genet. Evol. 2015, 34, 361-371. [CrossRef]

211. Al-Bassam, L.S.; Al-Garib, S.O.; El-Attar, S.R.; Abdunaser, E.; Abdouslam, O.E. Diagnosis of Bovine Anaplasma marginale in North Western Libya Using Serology and Blood Film Examination: A Comparative Study. Basrah J. Vet. Res. 2016, 15, 119-131.

212. Elhariri, M.D.; Elhelw, R.A.; Hamza, D.A.; Soliman, D.E. Molecular Detection of Anaplasma marginale in the Egyptian water buffaloes (Bubalus bubalis) based on major surface protein 1 $\alpha$. J. Chem. Inf. Model. 2017, 47, 247-252.

213. Zaid, T.; Ereqat, S.; Nasereddin, A.; Al-jawabreh, A. Molecular characterization of Anaplasma and Ehrlichia in ixodid ticks and reservoir hosts from Palestine: A pilot survey. Vet. Med. Sci. 2019, 5, 230-242. [CrossRef]

214. Muramatsu, Y.; Ukegawa, S.Y.; El Hussein, A.R.M.; Rahman, M.B.A.; Gabbar, K.M.A.A.; Chitambo, A.M.; Komiya, T.; Mwase, E.T.; Morita, C.; Tamura, Y. Ehrlichia ruminantium, Sudan. Emerg. Infect. Dis. 2005, 11, 10-11. [CrossRef]

215. Loftis, A.D.; Reeves, W.K.; Szumlas, D.E.; Abbassy, M.M.; Helmy, I.M.; Moriarity, J.R.; Dasch, G.A. Rickettsial agents in Egyptian ticks collected from domestic animals. Exp. Appl. Acarol. 2006, 40, 67-81. [CrossRef]

216. Hoogstraal, H. Ticks in relation to human diseases caused by Rickettsia species. Annu. Rev. Entomol. 1967, 12, 377-420. [CrossRef]

217. Nafi, O.; Tarawnah, Y.; Tarawnah, A. Epidemiological evaluation of Mediterranean spotted fever in children of the Karak province in south Jordan. J. Infect. Dev. Ctries. 2017, 11, 242-246. [CrossRef] [PubMed]

218. Fellers, F.X. An outbreak of Q fever: Clinical study. U.S. Armed Forces Med. J. 1952, 3, 287-295. [PubMed]

219. Adham, F.K.; Abdel-samie, E.; Gabre, R.M.; Hala, E.H. Detection of tick blood parasites in Egypt using PCR assay II- Borrelia burgdorferi sensu lato. J. Egypt. Soc. Parasitol. 2010, 40, 553-564. [PubMed]

220. Elhelw, R.A.; El-enbaawy, M.I.; Samir, A. Acta Tropica Lyme borreliosis: A neglected zoonosis in Egypt. Acta Trop. 2014, 140, 188-192. [CrossRef] [PubMed]

221. Kirk, R. The Epidemiology of Relapsing Fever in the Anglo-Egyptian Sudan. Ann. Trop. Med. Parasitol. 1939, 33, 125-140. [CrossRef]

222. Rebaudet, S.; Parola, P. Epidemiology of relapsing fever borreliosis in Europe. FEMS Immunol. Med. Microbiol. 2006, 48, 11-15. [CrossRef]

223. Assous, M.V.; Wilamowski, A. Relapsing fever borreliosis in Eurasia-forgotten, but certainly not gone! Clin. Microbiol. Infect. 2009, 15, 407-414. [CrossRef] [PubMed]

224. Trevisanato, S.I. Did an epidemic of tularemia in Ancient Egypt affect the course of world history? Med. Hypotheses 2004, 63, 905-910. [CrossRef] [PubMed]

225. Trevisanato, S.I. The "Hittite plague", an epidemic of tularemia and the first record of biological warfare. Med. Hypotheses 2007, 69, 1371-1374. [CrossRef] [PubMed]

226. Gürcan, Ş. Epidemiology of tularemia. Balkan Med. J. 2014, 31, 3-10. [CrossRef] [PubMed]

227. Ghoneim, N.H.; Abdel-Moein, K.A.; Zaher, H.M. Molecular detection of Francisella spp. among ticks attached to camels in Egypt. Vector-Borne Zoonotic Dis. 2017, 17, 384-387. [CrossRef] [PubMed] 
228. Perveen, N.; Muzaffar, S.B.; Vijayan, R.; Ali, M.; Deeb, A. Microbial communities associated with the camel tick, Hyalomma dromedarii: 16S rRNA gene-based analysis. Sci. Rep. 2020, 10, 1-11. [CrossRef] [PubMed]

229. Hadi, A.M.; Al-Amery, A.M.A. Isolation of Theileria and Babesia from Gut and Overy of Hard Ticks: Hyalomma a. anatolicum in Baghdad. Diyala Agric. Sci. J. 2012, 4, 1-8.

230. Swelum, A.A.; Ismael, A.B.; Khalaf, A.F.; Abouheif, M.A. Clinical and laboratory findings associated with naturally occurring babesiosis in dromedary camels. Bull. Vet. Inst. Pulawy 2014, 58, 229-233. [CrossRef]

231. Abdullah, S.H.; Mohammed, A.A. Babesiosis of small ruminants in Sulaimani city Kurdistan-Iraq. AL-Qadisiya J. Vet. Med. Sci. 2014, 13, 39-43. [CrossRef]

232. Uilenberg, G.; Franssen, F.F.J.; Perié, N.M. Stage-specific antigenicity in Theileria annulata: A case report. Vet. Q. 1986, 8, 73-75. [CrossRef]

233. Jacquiet, P.; Dia, M.L.; Perié, N.M.; Jongejan, F.; Uilenberg, G.; Morel, P.C. Présence de Theileria annulata en Mauritanie. Rev. D'élevage Méd. Vét. Des Pays Trop. 1990, 43, 489-490.

234. Jacquiet, P.; Colas, F.; Cheikh, D.; Thiam, E.; Ly, B.A. Epidémiologie descriptivede la theilériose bovine à Theileria annulata en Mauritanie, l'Afrique de l'Ouestsub-saharienne. Rev. Elev. Méd. Vét. Pays Trop. 1994, 47, 147-155.

235. Tageldin, M.H.; Fadiya, A.A.K.; Sabra, A.A.Y.; Ismaily, S.I.A.I. Theileriosis in sheep and goats in the Sultanate of Oman. Trop. Anim. Health Prod. 2005, 37, 491-493. [CrossRef]

236. Al-Saeed, A.T.M.; Omer, L.T.; Abdo, J.; Habibi, G.; Salih, D.A.; Seitzer, U.; Ahmed, J. Epidemiological studies on tropical theileriosis (Theileria annulata infection of cattle) in Kurdistan Region, Iraq. Parasitol. Res. 2010, 106, 403-407. [CrossRef] [PubMed]

237. Shayan, P.; Ebrahimzadeh, E.; Tageldin, M.H.; Amininia, N.; Eckert, B. Molecular study of sheep malignant theileriosis at Barka region in the Sultanate of Oman. Iran. J. Parasitol. 2011, 6, 66-72. [PubMed]

238. Al-Hamidhi, S.; Tageldin, M.H.; Weir, W.; Al-Fahdi, A.; Johnson, E.H.; Bobade, P.; Alqamashoui, B.; Beja-Pereira, A.; Thompson, J.; Kinnaird, J.; et al. Genetic diversity and population structure of Theileria annulata in Oman. PLoS ONE 2015, 10, 1-16. [CrossRef] [PubMed]

239. Al-Fahdi, A.; Alqamashoui, B.; Al-hamidhi, S.; Kose, O. Molecular surveillance of Theileria parasites of livestock in Oman. Ticks Tick Borne Dis. 2017, 8, 741-748. [CrossRef] [PubMed]

240. Charrel, R.N.; Zaki, A.M.; Attoui, H.; Fakeeh, M.; Billoir, F.; Yousef, A.I.; De Chesse, R.; De Micco, P.; Gould, E.A.; Lamballerie, X De Complete Coding Sequence of the Alkhurma Virus, a Tick-Borne Flavivirus Causing Severe Hemorrhagic Fever in Humans in Saudi Arabia. Biochem. Biophys. Res. Commun. 2001, 287, 455-461. [CrossRef] [PubMed]

241. Whitehouse, C.A. Crimean-Congo hemorrhagic fever. Antivir. Res. 2004, 64, 145-160. [CrossRef]

242. Ergönül, O. Crimean-Congo haemorrhagic fever. Lancet Infect. Dis. 2006, 6, 203-214. [CrossRef]

243. Wernery, U. Zoonoses in the Arabian Peninsula. Saudi Med. J. 2014, 35, 1455-1462.

244. Kunze, U. The International Scientific Working Group on Tick-Borne Encephalitis (ISW TBE): Review of 17 years of activity and commitment. Ticks Tick Borne Dis. 2016, 7, 399-404. [CrossRef]

245. Katargina, O.; Russakova, S.; Geller, J.; Kondrusik, M.; Zajkowska, J.; Zygutiene, M.; Bormane, A.; Trofimova, J.; Golovljova, I. Detection and Characterization of Tick-Borne Encephalitis Virus in Baltic Countries and Eastern Poland. PLoS ONE 2013, 8, e61374. [CrossRef]

246. Mansfield, K.L.; Johnson, N.; Phipps, L.P.; Stephenson, J.R.; Fooks, A.R.; Solomon, T. Tick-borne encephalitis virus-A review of an emerging zoonosis. J. Gen. Virol. 2009, 90, 1781-1794. [CrossRef] [PubMed]

247. Soleng, A.; Edgar, K.S.; Paulsen, K.M.; Pedersen, B.N.; Okbaldet, Y.B.; Skjetne, I.E.B.; Gurung, D.; Vikse, R.; Andreassen, K. Distribution of Ixodes ricinus ticks and prevalence of tick-borne encephalitis virus among questing ticks in the Arctic Circle region of northern Norway. Ticks Tick Borne Dis. 2018, 9, 97-103. [CrossRef] [PubMed]

248. Zaki, A.M. Isolation of a flavivirus related to the tick-borne encephalitis complex from human cases in Saudi Arabia. Trans. R. Soc. Trop. Med. Hyg. 1997, 91, 179-181. [CrossRef]

249. Kocan, K.M.; de la Fuente, J.; Blouin, E.F.; Coetzee, J.F.; Ewing, S.A. The natural history of Anaplasma marginale. Vet. Parasitol. J. 2010, 167, 95-107. [CrossRef]

250. Inci, A.; Yildirim, A.; Duzlu, O.; Doganay, M.; Aksoy, S. Tick-Borne Diseases in Turkey: A Review Based on One Health Perspective. PLoS Negl. Trop. Dis. 2016, 10, 1-12. [CrossRef]

251. Dumler, J.S.; Choi, K.; Garcia-garcia, J.C.; Barat, N.S.; Scorpio, D.G.; Garyu, J.W.; Grab, D.J.; Bakken, J.S. Human Granulocytic Anaplasmosis and Anaplasma phagocytophilum. Emerg. Infect. Dis. 2005, 11, 1828. [CrossRef]

252. Parola, P.; Paddock, C.D.; Raoult, D. Tick-borne rickettsioses around the world: Emerging diseases challenging old concepts. Clin. Microbiol. Rev. 2005, 18, 719-756. [CrossRef]

253. Dumler, J.S.; Barbet, A.F.; Bakker, C.P.; Dasch, G.A.; Palmer, G.H.; Ray, S.C.; Rikihisa, Y.; Rurangwira, F.R. Reorganization of gene in families Rickettsiaceae and Anaplasmataceae in the order Rickettsiales: Unification of some species of Ehrlichia with Anaplasma, Cowdria with Ehrlichia with neorickettsia, description of six new species combinations and designatio. Int. J. Syst. Evol. Microbiol. 2001, 51, 2145-2165. [CrossRef]

254. Raoult, D.; Roux, V. Rickettsioses as paradigms of new or emerging infectious diseases. Clin. Microbiol. Rev. 1997, 10, 694-719. [CrossRef]

255. Walker, D.H.; Ismail, N. Emerging and re-emerging rickettsioses: Endothelial cell infection and early disease events. Nat. Rev. Micro 2008, 6, 375-386. [CrossRef] 
256. Margos, G.; Vollmer, S.A.; Cornet, M.; Garnier, M.; Fingerle, V.; Wilske, B.; Bormane, A.; Vitorino, L.; Collares-pereira, M.; Drancourt, M.; et al. A New Borrelia Species Defined by Multilocus Sequence Analysis of Housekeeping Genes. Appl. Environ. Microbiol. 2009, 75, 5410-5416. [CrossRef] [PubMed]

257. Arco, C.D.; Dattwyler, R.J.; Arnaboldi, P.M. Borrelia burgdorferi-specific IgA in Lyme Disease. EBioMedicine 2017, 19, 91-97. [CrossRef]

258. Kilpatrick, A.M.; Dobson, A.D.M.; Levi, T.; Salkeld, D.J.; Swei, A.; Ginsberg, H.S.; Kjemtrup, A.; Padgett, K.A.; Jensen, P.M.; Fish, D.; et al. Lyme disease ecology in a changing world: Consensus, uncertainty and critical gaps for improving control. Phil. Trans. R. Soc. B 2018, 372, 1-15. [CrossRef] [PubMed]

259. Pritt, B.S.; Mead, P.S.; Johnson, D.K.H.; Neitzel, D.F.; Respicio-, L.B.; Davis, J.P.; Schiffman, E.; Sloan, L.M.; Schriefer, M.E.; Adam, J.; et al. Identification of a novel pathogenic Borrelia species causing Lyme borreliosis with unusually high spirochaetaemia: A descriptive study. Lancet Infect. Dis. 2016, 16, 556-564. [CrossRef]

260. Stanek, G.; Wormser, G.P.; Gray, J.; Strle, F. Lyme borreliosis. Lancet 2012, 379, 461-473. [CrossRef]

261. Re III, L.V.; Occi, J.L.; Macgregor, R.R. Identifying the Vector of Lyme Disease. Am. Fam. Physician 2004, 69, $1935-1937$.

262. Cutler, S.J. Possibilities for Relapsing Fever Reemergence. Emerg. Infect. Dis. 2006, 12, 369-374. [CrossRef]

263. Jellison, W.L. Tularemia in North America, 1930-1974; University of Montana: Missoula, MT, USA, 1974.

264. Eisen, L. A call for renewed research on tick-borne Francisella tularensis in the Arkansas-Missouri primary national focus of tularemia in humans. J. Med. Entomol. 2007, 44, 389-397. [CrossRef]

265. Uilenberg, G. Babesia-A historical overview. Vet. Parasitol. 2006, 138, 3-10. [CrossRef]

266. Ranjbar-Bahadori, S.; Eckert, B.; Omidian, Z.; Shirazi, N.S.; Shayan, P. Babesia ovis as the main causative agent of sheep babesiosis in Iran. Parasitol. Res. 2012, 110, 1531-1536. [CrossRef]

267. Youssef, S.Y.; Yasien, S. Vector identification and clinical, hematological, biochemical, and parasitological characteristics of camel (Camelus dromedarius) theileriosis in Egypt. Trop. Anim. Health Prod. 2015, 47, 649-656. [CrossRef] [PubMed]

268. Florin-christensen, M.; Schnittger, L. Piroplasmids and ticks: A long-lasting intimate relationship. Front. Biosci. 2009, 14, 3064-3073. [CrossRef] [PubMed]

269. Miranda-De La Lama, G.C.; Villarroel, M.; María, G.A. Livestock transport from the perspective of the pre-slaughter logistic chain: A review. MESC 2014, 98, 9-20. [CrossRef] [PubMed]

270. De Meneghi, D.; Stachurski, F.; Adakal, H. Experiences in Tick Control by Acaricide in the Traditional Cattle Sector in Zambia and Burkina Faso: Possible Environmental and Public Health Implications. Front. Public Health 2016, 4, 1-11. [CrossRef] [PubMed]

271. George, J.E.; Pound, J.M.; Davey, R.B. Chemical control of ticks on cattle and the resistance of these parasites to acaricides. Parasitology 2004, 129, S353-S366. [CrossRef] [PubMed]

272. Rottier, E.; Ince, M. Chapter 2 Disease and disease transmission. In Controlling and Preventing Disease; Loughborough University: Loughbor-ough, UK, 2005; pp. 7-27.

273. Lederberg, J.; Shope, R.; Oaks, S. Emerging Infections: Microbial Threats to Health in the United States.; National Academy Press: Washington, DC, USA, 1992.

274. Smolinski, M.; Hamburg, M.; Lederberg, J. Microbial Threats to Health: Emergence, Detection, and Response; National Academies Press: Washington, DC, USA, 2003.

275. Jones, K.E.; Patel, N.G.; Levy, M.A.; Storeygard, A.; Balk, D.; Gittleman, J.L.; Daszak, P.; Park, R.; Trust, W. Global trends in emerging infectious diseases Kate. Nature 2008, 451, 990-993. [CrossRef]

276. Wikel, S.K. Ticks and Tick-Borne Infections: Complex Ecology, Agents, and Host Interactions. Vet. Sci. 2018, 5, 60. [CrossRef]

277. Krause, R. Dynamics of emergence. J. Infect. Dis. 1994, 170, 265-271. [CrossRef]

278. Morse, S. Factors in the emergence of infectious diseases. Emerg. Infect. Dis. 1995, 1, 7-15. [CrossRef]

279. Weiss, R.; McMichael, A. Social and environmental risk factors in the emergence of infectious diseases. Nat. Med. 2004, 10, S70-S76. [CrossRef]

280. Morse, S. Emerging Viruses; Oxford University Press: New York, NY, USA, 1993.

281. Heyman, P.; Cochez, C.; Hofhuis, A.; Sprong, H.; Porter, S.R.; Losson, B.; Saegerman, C.; Donoso-mantke, O.; Niedrig, M. A clear and present danger: Tick-borne diseases in Europe. Expert Rev. Anti Infect. Ther. 2010, 8, 33-50. [CrossRef] [PubMed]

282. Mertins, J.W.; Schlater, J.L. Exotic ectoparasites of ostriches recently imported into the United States. J. Wildl. Dis. 1991, 27, 180-182. [CrossRef]

283. Keirans, J.E.; Durden, L.A. Invasion: Exotic ticks (Acari: Argasidae, Ixodidae) imported into the United States. A review and new records. J. Med. Entomol. 2001, 38, 850-861. [CrossRef] [PubMed]

284. Gonzalez, J.P.; Camicas, J.L.; Cornet, J.P.; Faye, O.; Wilson, M. Sexual and transovarian transmission of Crimean-Congo haemorrhagic fever virus in Hyalomma truncatum ticks. Res. Virol. 1992, 143, 23-28. [CrossRef]

285. Mathison, B.A.; Gerth, W.J.; Pritt, B.S.; Clinic, M.; Baugh, S.; Medical, L.; Northwest, G. Introduction of the exotic tick Hyalomma truncatum on a human with travel to Ethiopia: A Case Report. Ticks Tick-Borne Dis. 2015, 6, 152-154. [CrossRef] [PubMed]

286. Hoogstraal, H.; Oliver, R.M.; Guirgis, S.S. Larva, Nymph, and Life Cycle of Ornithodoros (Alectorobius) muesebecki (Ixodoidea: Argasidae), a Virus-Infected Parasite of Birds and Petroleum Industry Employees in the Arabian Gulf1. Ann. Entomol. Soc. Am. 1970, 63, 1762-1768. [CrossRef]

287. Goddard, J. Physician's Guide to Arthropods of Medical Importance; CRC Press: Boca Raton, FL, USA, 2012. 
288. Beati, L.; Meskini, M.; Thiers, B.; Raoult, D. Rickettsia aeschlimannii sp. nov., a new spotted fever group of rickettsia associated with Hyalomma marginatum ticks. Int. J. Syst. Bacteriol. 1997, 47, 548-554. [CrossRef]

289. Doğan, M.; Devge, C.; Pata, Y.T.; Sönmezoğlu, M. Case report: Facial nerve paralysis due to intra-aural Hyalomma tick infestation. Turiye Parazitol. Derg. 2012, 36, 254-257. [CrossRef]

290. Estrada-Pena, A. Tick-borne pathogens, transmission rates and climate change. Front. Biosci. 2009, 14, 2674-2687. [CrossRef]

291. Ogden, N.H.; Bigras-poulin, M.; Callaghan, C.J.O.; Barker, I.K.; Lindsay, L.R. A dynamic population model to investigate effects of climate on geographic range and seasonality of the tick Ixodes scapularis. Int. J. Parasitol. 2005, 35, 375-389. [CrossRef]

292. Dobson, A.D.M.; Finnie, T.J.R.; Randolph, S.E. A modified matrix model to describe the seasonal population ecology of the European tick Ixodes ricinus. J. Appl. Ecol. 2011, 48, 1017-1028. [CrossRef]

293. Eisen, R.J.; Eisen, L.; Ogden, N.H. Linkages of Weather and Climate with Ixodes scapularis and Ixodes pacificus (Acari: Ixodidae) Enzootic Transmission of Borrelia burgdorferi, and Lyme Disease in North America. J. Med. Entomol. 2017, 53, 250-261. [CrossRef] [PubMed]

294. Lindsay, L.R.; Mathison, S.W.; Barker, I.K.; McEwen, S.A.; Gillespie, T.J.; Surgeoner, G.A. Microclimate and Habitat in Relation to Ixodes scapularis (Acari: Ixodidae) Populations on Long Point, Ontario, Canada. J. Med. Entomol. 1999, 33, 255-262. [CrossRef] [PubMed] 